NBER WORKING PAPER SERIES

\title{
DID LATE NINETEENTH CENTURY U.S. TARIFFS \\ PROMOTE INFANT INDUSTRIES? \\ EVIDENCE FROM THE TINPLATE INDUSTRY
}

\author{
Douglas A. Irwin \\ Working Paper 6835 \\ http://www.nber.org/papers/w6835 \\ NATIONAL BUREAU OF ECONOMIC RESEARCH \\ 1050 Massachusetts Avenue \\ Cambridge, MA 02138 \\ December 1998
}

I wish to thank seminar participants at Yale, UNH, and the NBER Summer Institute for their helpful comments. The views expressed here are those of the author and do not reflect those of the National Bureau of Economic Research.

(C) 1998 by Douglas A. Irwin. All rights reserved. Short sections of text, not to exceed two paragraphs, may be quoted without explicit permission provided that full credit, including $\mathbb{C}$ notice, is given to the source. 
Did Late Nineteenth Century U.S. Tariffs Promote

Infant Industries? Evidence from the Tinplate Industry

Douglas A. Irwin

NBER Working Paper No. 6835

December 1998

JEL No. F13, N71

\section{ABSTRACT}

This paper examines the role of late nineteenth century U.S. tariffs in promoting infant industries by focusing on the much heralded example of the tinplate industry. After earlier failures, the tinplate industry became established and flourished after receiving protection in the McKinley tariff of 1890 . Treating the entry and exit decisions of producers as endogenous, a probability model is estimated to determine the conditions under which domestic tinplate production will take place. Counterfactual simulations indicate that, in the absence of the McKinley duties, domestic tinplate production would have arisen about a decade later as U.S. iron and steel prices (comprising threequarters of production costs) converged with those in Britain. While the tariff accelerated the industry's development, welfare calculations suggest that protection does not pass a cost-benefit test.

Douglas A. Irwin

Department of Economics

Dartmouth College

Hanover, NH 03755

and NBER

douglas.irwin@dartmouth.edu 


\section{Introduction}

The United States rapidly industrialized in the late nineteenth century and, around the turn of the century, became not just a net exporter of manufactured goods for the first time, but the world's leading producer of such goods. This industrial expansion occurred during a period of high import tariffs, raising the question of whether protection contributed to the U.S. success in manufacturing by fostering the growth of infant industries. Agreeing with those who later found it difficult to rule out a possible beneficial role of tariffs during this period, Frank Taussig (1915, p. 153) stated that "there is a prima facie case for the protectionist, - again an apparent confirmation of the validity of the young industries argument, - from the nature and extent of the industrial development during the last two decades of the nineteenth century."

Yet Taussig remained agnostic, however, because he recognized that the impact of protection can be determined only by answering a counterfactual question about how an industry would have developed in the absence of the tariff. This counterfactual is particularly important in considering the iron and steel industry, where the strongest candidates for examples of "successful" protection have tended to be. America's abundance of natural resources, such as iron ore and coal in Pennsylvania and elsewhere, has led many to believe that the U.S. iron and steel industry would have developed at some point anyway, even without the benefit of

1 Although skeptical of antebellum infant industry protection, Taussig (1915, p. 21) was so impressed by the post-Civil War industrial expansion that, "notwithstanding early prepossessions to the contrary, I am disposed to admit that there is scope for protection to young industries even in such a later stage of development." 
protection. Taussig (1915, p. 151) himself suggested that "the same sort of growth [in iron and steel] would doubtless have taken place eventually, tariff or no tariff; but not so soon or on so great a scale." 2

Such assertions require substantiation, and if true the question then becomes one of whether it proved worthwhile to impose protective tariffs in order to establish domestic production of a product in advance of when it otherwise would have arisen. This paper investigates such issues by focusing on a segment of the iron and steel industry that has been heralded as possibly the best example of infant industry protection. The experience of the tinplate industry, which produces thin sheets of iron or steel that have been coated with tin, is unique on several dimensions:

! Unlike most manufacturing industries, tinplates did not receive significant tariff protection after the Civil War, apparently due to a mistaken interpretation of the tariff code. Left without adequate protection, there was virtually no domestic production prior to 1890 .

! The McKinley tariff of 1890 substantially raised the duty on imported tinplate to encourage the entry and growth of domestic producers. The act also contained an unusual provision in which the tariff would be completely eliminated in six years if, by that time, domestic production did not amount to at least one-third of imports.

! The tariff succeeded in promoting domestic production and output rapidly expanded,

2 Others have endorsed Taussig's judgment. Berglund and Wright (1929, p. 134) maintain that "whatever had been our policy with respect to the tariff, the United States would have developed a great iron and steel industry." Hogan (1971, p. 357) argues that "it seems inevitable that with our resources of ore and coal that the United States would naturally have been an iron and steel producer," although "it also seems probable that British competition might have hindered the proper growth of the industry in the early years." Wright (1990) discusses the importance of raw materials abundance for U.S. manufacturing during this period. 
despite a tariff reduction during 1894-97. By about 1910, the price of U.S. tinplates fell below those produced in the United Kingdom and the United States became a net exporter.

The tinplate example has all the elements of an apparently successful application of infant industry protection. The industry failed to receive protection initially, and it clearly did not develop until protection was applied. The industry improved rapidly and domestic prices fell to the world price level within two decades. But the counterfactual question remains: would the industry have developed anyway, and were the tariffs worthwhile?

This paper seeks to determine whether the tinplate industry would have developed at some point without the benefit of protection, and what the welfare consequences of that protection were. Section II discusses the search for infant industries in the late nineteenth century United States and why the tinplate industry is of special interest. Section III analyzes the barriers to establishing domestic tinplate production by focusing on the industry's cost structure, particularly raw materials expenses and dynamic scale economies resulting from learning by doing. Section IV develops an empirical model in which the decision of domestic firms to produce tinplate is treated as endogenous. The estimated model is then subjected to various counterfactual scenarios, such as the removal of the McKinley tariff, to determine the timing of entry in different circumstances. Section V estimates the welfare impact of the McKinley tariff, and Section VI summarizes the paper's conclusions.

To anticipate the paper's main conclusions, the analysis here suggests that, in the absence of the McKinley tariff, the U.S. tinplate industry would have established itself about a decade later, and that over this time horizon the McKinley duty fails to pass a cost-benefit test. 


\section{Searching for Late Nineteenth Century Infant Industries: The Case of Tinplate}

Perhaps the most famous statement of the infant industry case for protection came from John Stuart Mill, who wrote that tariffs may be beneficial "when they are imposed temporarily (especially in a young and rising nation) in hopes of naturalizing a foreign industry, in itself perfectly suitable to the circumstances of the country." Mill argued that one country's advantage in a certain industry may be due only to its having begun production sooner: "There may be no inherent advantage on one part, or disadvantage on the other, but only a present superiority of acquired skill and experience." Temporary protection could be applied by a country in which the industry could be fertile because "it cannot be expected that individuals should, at their own risk, or rather to their certain loss, introduce a new manufacture, and bear the burthen of carrying it on until the producers have been educated up to the level of those with whom the processes are traditional" (quoted in Irwin 1996, p. 128).

Import tariffs were frequently justified on infant industry grounds in the nineteenth century United States. Yet surprisingly, as Anne Krueger and Baran Tuncer (1982, p. 1142) note, "there has been virtually no systematic examination of the empirical relevance of the infant industry argument" - during this or any other period. ${ }^{3}$ Krueger and Tuncer propose to evaluate such protection by examining the relationship between various measures of trade protection and total factor productivity growth across industries. ${ }^{4}$ Applying their approach to the turn-of-the-century

3 Paul David (1970) and Jeffrey Williamson (1972), however, have debated the evidence on infant industry protection for the antebellum U.S. cotton textile industry.

4 Using data from Turkey, Krueger and Tuncer (1982) concluded that there was no tendency for productivity to advance more rapidly in protected industries, although they presented no statistical test of this claim. Ann Harrison (1994) later showed that some of their measures of protection and productivity growth were positively correlated. Krueger and Tuncer (1994) 
United States, Table 1 presents Spearman rank correlations between three measures of trade protection (the nominal tariff and two calculations of the effective rate of protection) in 1899 and several measures of sectoral economic performance between 1899-1909. ${ }^{5}$ The Spearman rank correlation between ERP (B) — the conceptually correct measure of effective protection when the underlying data are drawn from a tariff-inclusive equilibrium — and total factor productivity for 14 sectors is found to be 0.27 , but not statistically significant at standard confidence levels.

Any interpretation of these broad sectoral correlations, however, is plagued by numerous difficulties. First, the measures of policy intervention are poor because input substitution can render calculations of the effective rates of protection meaningless in general equilibrium. Second, the specific timing of productivity changes in relation to protection can always be questioned, particularly in this period when the tariff is roughly constant over time. Third, the sectoral definitions are so broad as to possibly encompass both leading and lagging industries, masking the role of the tariff in particular cases. Finally, and perhaps most importantly, no attempt is made to control for other factors determining productivity at the same time. Furthermore, any specific result is uninformative: how does one assess whether, as in this case, 0.27 is a high or a low correlation? Is this sufficient to prove anything about infant industries when there is no well-specified benchmark or alternative?

These problems force us to take up Taussig's (1915, p. 29) suggestion that the best

argued in reply that the difference in productivity growth between protected and non-protected sectors was insufficient to make protection economically worthwhile.

5 Data limitations preclude consideration of different time periods in the late nineteenth century. The correlation between the nominal tariff and the effective tariff is similar to that reported in Hawke (1975). 
approach to analyzing infant industry protection is "by direct investigation of the particular cases." But despite the breadth of the late nineteenth century U.S. industrial expansion, surprisingly few candidates have been proposed as successful instances of such protection. ${ }^{6}$ Cotton and woollen manufactures were, by this time, old industries that had been protected for decades. Taussig and others favorably mention the silk industry as one that successfully matured under protection, but this industry apparently required substantial, ongoing protection. Protection surely succeeded in increasing domestic output in these cases, but advantageous infant industry protection requires that the domestic industry's prices soon fall to the world level (or perhaps that the industry can profitably export at world prices) so that the present discounted value of social benefits exceeds that of the costs.

Two better cases appear in the iron and steel industry, specifically steel rails and tinplate. The steel rail industry grew rapidly under the protection it received after the Civil War, survived the phased reduction and eventual removal of import duties, saw their prices fall below those in the United Kingdom, and eventually began to export its products. In a paper discussed further below, Keith Head (1994) performs a counterfactual simulation of steel rail tariff policies in which country-specific learning by doing proves so important that, under free trade, the U.S. industry never begins production until almost 1913.

The tinplate industry differs from steel rails and nearly every other industries in that it did not receive significant protection initially, but only after decades had past with virtually no

6 Tedesco (1985, p. 190) writes that James Swank, the "ultra-protectionist" secretary of the American Iron and Steel Association, "had largely jettisoned whatever systematic theory protection had ever had" and "de-emphasized the basic 'infant industries' argument. Only in silk and tinplate was he ever able to claim vindication of protection for that purpose. Even then, he could not prove that these two manufactures would not have developed without protection." 
domestic production. ${ }^{7}$ The industry initially failed to receive protection because of a mistaken interpretation of the tariff code in 1864 by the Secretary of the Treasury, who erroneously moved a comma in the tariff act by just two words. ${ }^{8}$ As a result, instead of receiving a more than 50 percent ad valorem tariff implied by the 1864 act, imported tinplates were construed as falling under a different section of the tariff code in which they received a 15 percent duty. This mistake provides us with the rare opportunity to observe what would happen to a manufacturing industry that did not receive protection during this period.

As a result of the Treasury decision, there was no domestic production in the late $1860 \mathrm{~s}$ and virtually all of U.S. consumption was served by imports from the United Kingdom, where production was highly concentrated in South Wales. (Wales exported roughly three-quarters of its output to the United States.) U.S. demand for tinplate grew steadily through the late nineteenth century as it proved useful in making cans to preserve food, drums to store and ship petroleum, sheets for roofing, and various household utensils. Despite the low level of tariff

${ }^{7}$ For general discussions of the tinplate industry, see Ayers (1897), Gray (1902), Dunbar (1915), and Minchinton (1957).

${ }^{8}$ The Tariff Act of 1864 provided for the following duty on imported tinplate: "On tinplates, and iron galvanized or coated with any metal by electric batteries or otherwise, two cents and a half per pound" (U.S. House of Representatives 1909, p. 233). At the time, a 2-1/2 cent specific duty on tinplate would have translated into an ad valorem tariff of over 50 percent. A month after Congress enacted this tariff, Secretary of the Treasury William Fessenden informed the customs collector in New York that there was an "error of punctuation" in the provision, "probably by the clerk who engrossed that part of the act," he speculated. If the comma after the word "tinplates" was moved to after the word "iron," Fessenden suggested, then "the true sense" of the provision would be clear, namely that "the tin plates as well as the iron must be galvanized or coated with any metal ... in order to bring them within the provision" (quoted in Tariff Commission 1883, p. 2082). Fessenden apparently did not realize exactly what tinplates are: not plates of tin coated with another metal, but plates of iron or steel that have been dipped in molten tin. The interpretation is clearly erroneous because no one has ever sought to coat tin or tinplates with another metal. 
protection, high prices for tinplate prompted three U.S. firms, begun at the initiative or with the assistance of Welsh immigrants, to begin producing tinplate in western Pennsylvania and eastern Ohio during 1872-74 (see Minchinton 1957, p. 63, and Clark 1929, p. 373).

Unfortunately for the U.S. producers, tinplate prices peaked in 1872 and then collapsed, as illustrated in Figure 1. The three fledgling firms claimed that Welsh exporters were deliberately "dumping" their products in order to drive them out of business. Indeed, the firms shut down production sequentially, one in 1874 , another in 1875 , and the last in 1877 . The price collapse, however, probably did not reflect "dumping" but rather what Minchinton (1957, p. 48) called the "recurrent problem of overproduction." The high margins for U.K. tinplate producers during the early 1870s, shown in Figure 2, had induced the entry of many other Welsh producers; there were roughly a third more mills operating in Wales in 1878 (a total of 229) than there had been a decade earlier. A Welsh producer association attempted to limit output and raise prices, but the result was "wholly ineffective" (ibid., pp. 49-50). Prices stabilized by the late 1870 s, but too late to help the U.S. firms. The timing of the price decline and subsequent modest rise, however, gave credence to the charges that Welsh producers deliberately raised their prices after having successfully eliminated their American rivals through dumping.

Tinplate interests agitated throughout the 1870 s and 1880 s for a higher tariff, but to no avail. The defunct tinplate producers appeared before the House Ways and Means Committee in 1877 to complain about the lack of adequate tariff protection, but achieved no remedy. ${ }^{9}$

9 The committee reported a bill to the House in which, in the words of William C. Cronemeyer (1931, p. 33), president of the U.S. Iron and Tin Plate Company, "the clause on tinplate was so worded that it could not have been misconstrued again and the proposed rate of duty was in harmony with the rates on other iron products." The bill, however, was never enacted. 
Domestic tinplate interests then appealed, unsuccessfully, to the Secretary of the Treasury for a reconsideration of the 1864 tariff interpretation. ${ }^{10}$ Tinplate interests then explained their plight to a sympathetic Tariff Commission, set up by Congress to recommend tariff reforms, but Congress ignored their advice and even reduced the duty to 1 cent per pound in $1883 .^{11}$

Finally, in 1890, William McKinley, the chairman of the House Ways and Means Committee who represented the Ohio region where tinplate producers had originally sought to establish production, embraced the tinplate cause and proposed a higher tariff. Despite the fact that protectionist Republicans controlled Congress, serious political obstacles stood in the way of establishing high duties on tinplate. While there was a domestic tinplate interest, there was no domestic tinplate production. Past efforts to establish production had demonstrably failed, and there was no assurance that new firms would enter the business or that they would be successful. Tinplate consumers - particularly the Standard Oil Company, the food canning industry, and the roofing industry, all of which used tinplate extensively — were well organized (the Tinplate Consumers's Association of the United States) and actively opposed the tariff hike. In light of these considerations, even the Republicans found it difficult to muster political support for higher tinplate duties. At the Ways and Means Committee's recommendation, the House passed by a single vote, $150-149$, an amendment to raise the tinplate duty to 2.2 cents per pound (see

${ }^{10}$ Treasury Secretary John Sherman stated that "I do not feel at liberty to place any other construction upon the law, especially in view of the fact that the changes in the tariff subsequent to 1864 as to this article have undoubtedly been made with a full knowledge, by Congress, of the action taken by this Department in the premises" (quoted in Tariff Commission 1883, p. 2081).

11 The Commission's report (1883, p. 20) suggested "that a moderate rate of duty will develop this important industry, and that wise public policy dictates that at least a part of the amount consumed in this country of so essential an article as tin plate should be produced here." 
Stanwood 1903, pp. 272ff).

Opponents of the duty fought aggressively in the Senate. To counter the fear that the duty would merely cost tinplate-consuming industries without ensuring domestic production, Senator William Spooner (R-WI) introduced an amendment in which the 2.2 cents per pound duty would be effective only from 1 July 1891 (not 1 October 1890, when the McKinley tariff went into effect) and included the following unusual provision: "after October 1, 1897, tin and terne plates . . should be admitted free of duty, unless it shall be made to appear to the satisfaction of the President that the aggregate quantity of such plates ... produced in the United States during any of the six years next preceding June 30,1897 , has equaled one third of the amount of such plates imported and entered for consumption during any fiscal year after the passage of this act and prior to said October 1, 1897” (U.S. House of Representatives 1909, p. 379). Thus, protection was to be conditional or probationary to see if domestic tinplate production was viable. (Of course, Congress could not commit itself to enforcing this particular provision.) Tinplate interests disliked this condition, but accepted it, given their precarious political position, and the provision was enacted.

The McKinley duty sharply increased protection to the industry. Figure 3, depicting the specific duty levied on tinplate and its ad valorem equivalent, indicates that the McKinley act pushed the tariff from about 30 percent to over 70 percent. ${ }^{12}$ Tinplate imports from Wales surged

12 Democrats took a dim view of the tinplate tariff, saying that it "involved a new and distinct perversion of the Federal taxing power by making present, tangible, and profitable industries the sport and prey of prospective, conjectural, and speculative adventures" (U.S. House of Representatives 1892, p. 2). In 1894 they cut the tinplate duty to 1.2 cents per pound, equivalent to about 50 percent ad valorem (see Figure 3). The Republicans raised the duty to 1.5 cents per pound in 1897, but by this time the industry was firmly established. Subsequent tariff changes appear to have had little effect on the industry. 
in to beat the imposition of the duty, but shrank thereafter. Many firms entered the industry and domestic production, closely monitored by government agents, increased sharply (see Ayer 1897 and Gray 1902). Figure 4 illustrates how domestic production soared after 1891, matching the quantity of imports by 1896 and capturing nearly 90 percent of the market by 1899. By 1899 , there were 57 U.S. tinplate firms in operation, 35 of which rolled their own iron and steel plates while the others purchased those plates from U.S. and U.K. producers and just engaged in the tin dipping operation (Gray 1902, pp. 99-100).

The success of the tinplate industry was greeted with tremendous enthusiasm by its proponents. "The growth of this industry was heralded in the protectionist press as a dramatic illustration of the benefits of a high tariff," Clark (1929, p. 374) reports, "and consequently new entrepreneurs received an unusual amount of publicity .... though contemporary records of [the industry's] progress bear abundant evidence of juvenile exaggeration and evidence." In its annual report for 1892, for example, the American Iron and Steel Institute proudly proclaimed that "The McKinley tariff is entitled to the whole credit of establishing this new industry" (quoted in Hogan 1971, p. 353).

Later commentators also singled out the tinplate industry for distinction. "The most spectacular event in American metallurgical history" during the last two decades of the nineteenth century, Clark (1929, p. 372) declares, was "the final establishment of the tin plate industry under the stimulus of the McKinley tariff." While generally skeptical of iron and steel tariffs, Berglund and Wright (1929, p. 130) state that the "efficacy of the tariff in fostering a new industry is especially manifest in the case of tin and terneplate," an example "so striking that it calls for special mention." Temin (1964, p. 212) also suggests that tinplates provide an example of tariffs 
working out in the best possible way.

At the same time, the counterfactual question must be confronted. Taussig (1915, p. 178) believed that "the unexpected growth of the tin plate industry after 1890 was due chiefly to the cheapening of the fundamental raw material," namely, iron and steel bars. Knox (n.d., p. 12) argues that "it is a misconception for anyone to attribute the beginning of the tin plate industry in this country to the McKinley Tariff Act" because "this protective tariff hastened its start, but it was inevitable that American ingenuity and steel-making resources would have eventually accomplished the same results at some later date." Clark (1929, p. 375) also notes that "the United States afforded the largest market in the world for tin cans for preserving food stuffs and shipping petroleum, and for other tin containers," the implication being that some domestic tinplate production probably would have been established at some point anyway. ${ }^{13}$

\section{Barriers to Establishing Domestic Tinplate Production}

What factors prevented the establishment of domestic tinplate production prior to the McKinley tariff? Two potentially important determinants of an entrant's production costs were the prices of raw material inputs and the lack of previous production experience, i.e., dynamic scale economies resulting from learning by doing. The section seeks to ascertain the relative and absolute importance of these two factors.

Raw materials costs, particularly of the iron and steel sheets which were to be coated with tin, were critical for the tinplate industry. Iron and steel inputs accounted for nearly three-

13 The number of domestic canning firms grew from 97 in 1871 to 411 in 1880 to 886 in 1890 , all in a period in which there was no significant domestic tinplate production. See Minchinton (1957), p. 63. 
quarters of the cost of producing tinplate and about two-thirds of the value of tinplate. In 1899, the U.S. tin and terne plate industry used $\$ 20.7$ million worth of iron and steel to make tinplate that cost $\$ 28.6$ million (in materials and labor) to produce and which sold at a value of $\$ 31.9$ million, according to Census of Manufactures data (Gray 1902, pp. 100, 103). On this score, Welsh producers had a significant cost advantage over potential American rivals: due in part to high import tariffs, U.S. prices of iron and steel greatly exceeded U.K. prices for most of the late nineteenth century. As a result, iron and steel-using industries in the United States paid a significant premium for their inputs compared with their foreign counterparts.

Figure 5 plots the price premium on iron bar paid by U.S. tinplate producers vis-a-vis their Welsh rivals. ${ }^{14}$ In 1869 , the price of basic bar iron in the United States was double that in the United Kingdom, but the price differential rapidly fell to about 20 percent above that in the United Kingdom in the early 1870s. Through most of the 1880s, however, U.S. iron bar prices stood roughly 70 percent above those in the United Kingdom, but the premium declined again in the early 1890s until the prices were virtually equivalent by the turn of the century. Variation in the domestic price of iron bars appears closely related to the entry of U.S. tinplate producers: when the premium is high (1860s and 1880s), the effective protection given to domestic producers is significantly negative; when the premium is low (mid-1870s, mid-1890s), domestic tinplate

14 The price of steel billets would best represent the direct input costs to the tinplate industry, but I have been unable to find a long, consistent price series for both the United States and United Kingdom. However, the correlation between the U.S. prices of iron bars and steel billets is 0.94 for the shorter period of 1886-1913. Both data series can be found in the Statistical Abstract of the United States, various years 1895-1916. 
production is profitable. ${ }^{15}$ This is the basis for the belief that the declining input price premium would have enabled domestic tinplate producers to enter the industry eventually even without the aid of the McKinley tariff.

Another potential barrier to the establishment of domestic tinplate production, and one particularly relevant to the infant industry argument for protection, is the lack of previous production experience. If cumulative production experience significantly reduced production costs due to learning by doing, then late entrants in the industry could face a significant cost disadvantage compared to incumbents. In examining the steel rail industry, for example, Head (1994) finds significant learning effects, but assumes in his empirical analysis that there are perfect spillovers of learning-based knowledge between domestic firms but no spillovers between domestic and foreign firms. The assumption of no international spillovers, implying that subsequent entrants cannot adapt or build upon the production experience of the British leaders, essentially ensures that initial producers have an entrenched and virtually insurmountable advantage over subsequent rivals. This assumption may be responsible for Head's finding that, without a steel rail tariff, there would have been no U.S. production of steel rails until after $1910 .^{16}$

15 For example, using the basic formula for effective protection $-\left(t_{i}-a_{j i j} t_{j}\right) /\left(1-a_{j i}\right)-$ if iron and steel account for two-thirds of the cost of producing tinplate (i.e., $\mathrm{a}_{\mathrm{ij}}=0.67$ ) and the tariff on iron and steel is 75 percent (i.e., $\mathrm{t}_{\mathrm{j}}=0.75$ ), then a nominal tariff on tinplate of 25 percent delivers an effective rate of protection of -72 percent!

${ }^{16}$ Head (1994, p. 149) writes that "these assumptions, which appear frequently in the theoretical literature, seem appropriate if we think of accumulated knowledge as residing within entrepreneurs, engineers, and workers who either communicate with each other or move from one domestic firm to another but never move overseas." The assumption of no international spillovers was a "necessary simplification" and thought plausible, given the distances involved. Yet this period was also one of tremendous international labor mobility and the United States was the 
The tinplate industry appears to be characterized by both domestic and international technological and learning-based knowledge spillovers. Tinplate interests argued for tariff protection on the basis that domestic learning spillovers would enable the industry to reduce prices rapidly. As the president of the American Tin Plate Association maintained during the consideration of the McKinley tariff, "after we get 50 mills in this country and exchange our ideas we can reduce the price by the use of improved machinery and methods which they never thought of in the other countries" (U.S. House of Representatives 1890, p. 99). The domestic spillovers received specific impetus from a gentleman's agreement to facilitate the passage of the tinplate provision in the McKinley tariff. In order to obtain Senator Spooner's vote, the U.S. Iron and Tinplate Company, the first domestic entrant at this time, gave "consent to keep its mills open for inspection by and demonstration to any prospective Tinplate manufacturers and their engineers," according to the company's president, William Cronemeyer (1931, p. 45).

The international spillovers arose from the migration of skilled tinplate workers from Wales to the United States. The U.S. plants initiating production in the 1870 s were partly-owned or managed by Welshmen. These immigrants carried with them technical knowledge of tinplate production and essentially transplanted current Welsh production methods into the United States. After the imposition of the McKinley tariff, "Welsh manufacturers moved all or parts of their plants to America, though, since the tariff protected only the final dipping process, many still imported all the materials from Wales." Berthoff (1953, pp. 68-69) also states that "whether

principal destination for skilled European migrants. The assumption is hard to sustain in view of a 1901 report by a visiting party of British iron officials which noted that "a considerably number of the heads of the American iron industry of today acquired their training, their knowledge, and their experience in British works" (quoted in Berthoff 1953, p. 67). See also Hyde (1991). 
owned by Welshmen or Americans, the early works relied on the skill of Welsh tinners using Welsh machinery and Welsh techniques. Within a few years, however, as equipment and methods were improved, Welsh workmen no longer were necessary nor, over-fond of time-honored ways, even desirable." ${ }^{17}$ U.S. firms successfully recruited skilled Welsh labor and attracted them to the United States. That U.S. tinplate entrants could draw upon Welsh production techniques by hiring the skill and expertise of Welsh tinners suggests that they did not face insurmountable hurdles to entering the industry.

To provide some empirical evidence on the economic importance of raw materials costs and experience effects, a variant of the empirical strategy used by Head (1994) and Irwin and Klenow (1994) is employed. In lieu of cost data, prices are used to estimate the following cost markup equation which seeks to explain the components of the decline in tinplate prices observed in Figure 1. Suppressing time subscripts, the following specification is employed:

$$
\mathrm{p}_{\mathrm{US}}=\alpha \mathrm{mc}_{\mathrm{US}}=\alpha\left(\mathrm{pb}_{\mathrm{US}}\right)^{\beta}\left(\mathrm{q}_{\mathrm{US}}\right)^{\gamma}\left(\mathrm{E}_{\mathrm{US}}+\theta \mathrm{E}_{\mathrm{UK}}\right)^{\lambda}(\mathrm{t})^{\mu} \epsilon
$$

where $\mathrm{p}_{\mathrm{US}}$ is the U.S. price of tinplate, $\mathrm{mc}_{\mathrm{US}}$ is the U.S. marginal cost of production, $\mathrm{pb}_{\mathrm{US}}$ is the U.S. price of iron bars, $\mathrm{q}_{\mathrm{US}}$ is current domestic output, the experience variables $\mathrm{E}_{\mathrm{US}}$ and $\mathrm{E}_{\mathrm{UK}}$ represent the lagged cumulative production of U.S. and U.K. producers, respectively, $\mathrm{t}$ is a time trend, and $\epsilon$ is an error term. Taking logs, this equation becomes:

$$
\ln \left(\mathrm{p}_{\mathrm{US}}\right)=\alpha+\beta \ln \left(\mathrm{pb}_{\mathrm{US}}\right)+\gamma \ln \left(\mathrm{q}_{\mathrm{US}}\right)+\lambda \ln \left(\mathrm{E}_{\mathrm{US}}+\theta \mathrm{E}_{\mathrm{UK}}\right)+\mu \ln (\mathrm{t})+\epsilon,
$$

The estimated parameters can be interpreted as follows: $\alpha$ is the fixed and $\mu$ is the time-

17 As Taussig (1915, p. 185) also notes, "When the McKinley Act was passed in 1890, the tin plate mills first established in the United States were copied from the Welsh. Sometimes the whole equipment, — rolls, shears, pots, — was imported, and then was operated by Welshmen also brought over." 
varying markup over marginal cost, $\beta$ is the share of iron bar costs in production, $\gamma$ indicates the returns to scale, $\lambda$ is the effect of production experience (learning by doing) on costs, and $\theta$ is the weight placed on U.K. production experience. ${ }^{18}$ This formulation assumes that there is one common learning curve that depends upon production experience in both countries, thereby enabling an explicit test for international learning spillovers. This specification also assumes competitive pricing, not an unreasonable assumption given that there were over 200 mills in Wales and over 30 U.S. mills operating within just five years of the McKinley tariff (Gray 1902, p. 100).

Table 2 provides several different estimates of these equations. The first two columns present non-linear least squares estimates of equation (1) using annual data from 1869-1913. Though domestic firms chose an output level of zero for much of this period (in which case output is set to one in the equation), this regression examines the factors behind the decline in "potential" U.S. production costs because firms had the opportunity of selling at the U.S. price throughout this period. The results are presented with and without instruments for current output, an endogenous variable, using the instruments employed by Head (1994) including the ad

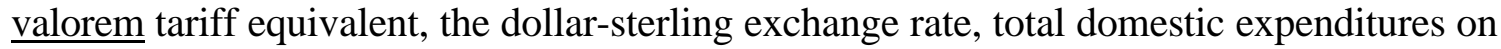
tinplates, and the other independent variables for the United States and the United Kingdom. The estimated coefficients are largely unaffected when instruments are used, although this likely reflects their low power.

The coefficient on the price of iron bars indicates that a $\$ 1$ increase in the price of iron

18 I have been unable to locate a wage index for iron and steel workers, although wages accounted for just 7 percent of the cost of producing tinplate in 1899 (Gray 1902, p. 100). 
bars would increase the price of tinplate by about $\$ 0.6$, consistent with the cost data discussed above. The coefficient on current output is 0.05 , which indicates slightly decreasing but essentially constant returns to scale in production. Cumulative production experience also appears to reduce costs, but the learning coefficient of -0.03 implies that a doubling of cumulative output would reduce costs by only 2 percent (calculated as $1-2^{\lambda}$ ). Thus, the effect of production experience on costs is trivial compared with the benefit of obtaining cheaper iron bars: a three percent decline in the price of iron bars would have the same effect on costs as a doubling of cumulative output. In view of the limited scope for cutting costs beyond the price of the necessary material inputs, as suggested by the flattening of U.K. margins after 1890 in Figure 2, this finding is perhaps not too surprising.

The regressions also confirm the importance of international learning-by-doing spillovers. The weight on U.K. production experience is 8 times that on domestic experience in the noninstrumented regression (with a p-value of 0.08), and 11 times that on domestic experience in the instrumented regression (with a p-value of 0.06). These parameter values indicates that Welsh production experience is extremely valuable for reducing U.S. production costs. Partly because they could adopt current Welsh production practices and technology and not start from scratch, U.S. producers were willing to enter the industry in 1891 at much lower tinplate prices than had prevailed in the past (as shown by Figure 1), despite their own lack of production experience.

Columns (3) and (4) present log linear (non-linear in parameters) estimates of equation (2) in which, as in Irwin and Klenow (1994), the parameter $\theta$ is estimated much less precisely, and appears to be smaller (but not insubstantial) in magnitude. Columns (5) and (6) consider the years 1891-1913 when U.S. firms were fully engaged in tinplate production. There appears to be no 
learning-by-doing during this period because both the price declines and the price-cost margin flatten out after about 1890. Column (7) presents results using only U.K. data and essentially confirms the findings from the U.S. regressions, i.e.., that the price of iron bars is the key component of production costs with production experience playing a smaller role (but larger here than in the U.S. case).

While these econometric results are not entirely conclusive, whether due to data limitations or the lack of instruments, several findings are consistent with other industry evidence. It is hard to describe the tinplate industry as one in which static or dynamic scale economies served as a barrier to new entrants. The large number of firms (and apparently easy entry of those

firms) suggests that there were no great economies of scale. Learning by doing has only a modest impact on costs, and what effect there is appears to be easily transferable internationally. The price of iron inputs looms large in the cost structure of tinplate, however, and will be examined in greater detail in the next section.

\section{Modeling the Domestic Production Decision}

This section develops an empirical model of the decision to produce tinplate in the United States. In the apparent absence of important industry scale economies, this decision depends simply upon the configuration of output prices and input costs necessary to make domestic production profitable. The parameters of this decision are estimated using annual data from 18691913 and exploit the fact that we observe domestic production in the period 1872-75, the subsequent exit of those producers from the market, and the re-entry of domestic producers from 1891. Once the parameters of the production decision have been estimated, the decision to 
produce can be reexamined based on counterfactual paths of the tariff and other variables of interest.

The decision to produce tinplate in the United States is modeled as follows:

$$
\operatorname{prob}\left(\mathrm{q}_{\mathrm{US}}>0\right)=\mathrm{F}\left(\mathrm{p}_{\mathrm{UK}}(1+\tau)-\delta \mathrm{c}_{\mathrm{UK}}\right)
$$

which states that the probability of domestic tinplate production $\left(\mathrm{q}_{\mathrm{US}}>0\right)$ is some increasing function of the profitability of domestic production, the elements of which are the U.K. price of tinplate $\left(\mathrm{p}_{\mathrm{UK}}\right)$, the ad valorem equivalent of the U.S. import tariff on tinplate $(\tau)$, the U.K. price of rolled iron bars $\left(\mathrm{c}_{\mathrm{UK}}\right)$, and the U.S. price premium on iron bars $(\delta$, usually $>1)$. In essence, the probability of domestic production in a given year is a function of three components: (i) $\mathrm{p}_{\mathrm{UK}}$ $\mathrm{c}_{\mathrm{UK}}$, the price-iron input cost margin in the United Kingdom, (ii) $\tau$, the ad valorem tariff on tinplate, and (iii) $\delta$, the U.S. price premium on iron bar inputs. The probability of domestic production is increasing with respect to the price-cost margin and the tariff, and decreasing with respect to the premium on iron inputs.

This model estimated as a probit in which the dependent variable indicates whether or not there is domestic production (i.e., taking the value 1 for the years $1872-75$ and 1891-1913, and 0 otherwise). Table 3 presents the marginal effects from the probit regression, which indicate the slope of the probability function (i.e., the change in the probability that $\mathrm{q}_{\mathrm{US}}>0$ ) for an infinitesimal change from the mean of the independent variables. If the errors from the regression are serially correlated, the probit estimates are still consistent and asymptotically normal, but inefficient (Poirier and Rudd 1988). Probit regressions are more sensitive to omitted variable bias and therefore various several specifications will be examined.

The first column regression includes variables for the import tariff and the iron price 
premium, which alone explain much of the decision of domestic producers. The marginal effects are nearly equal in magnitude and of the opposite sign. The second column adds a variable for the profitability of U.K. tinplate producers (the price-materials cost margin), which is both economically and statistically significant, and does not detract from the importance of the other variables.

The final column (3) adds the log of the value of U.S. tinplate consumption to see if entry is dependent upon market size effects, i.e., whether the domestic market must pass some critical threshold in order to induce the entry of domestic producers. This variable has a coefficient comparable in size to those on the other variables, is statistically significant, and does not detract from the economic or statistical significance of the other variables. The variable also adds to the overall explanatory power of the probit model, and therefore column (3) is the preferred specification.

In this specification, the marginal effect on the iron bar price variable is about two-thirds that on the tariff variable. This is remarkably consistent with both the Census of Manufactures data, which indicated that iron inputs comprised about two-thirds of the value of tinplate output, and the estimated cost coefficients from columns (1) and (2) of Table 2. The marginal effects here indicate that a 10 percent reduction in the iron price premium is economically as valuable to domestic producers as a 6-7 percent increase in the ad valorem tariff; in other words, a given percentage increase in the tariff is about 1.5 times more valuable to domestic producers than the same percentage decrease in the iron price premium.

Figure 6 plots the predicted probability of domestic production from the Table 3, column (3) regression with the shaded areas indicating periods of domestic production $(1872-74,1891-$ 
1913). While this equation accurately predicts these periods of domestic production, of greater interest is using the underlying coefficients to solve for the implied probability of domestic production under various counterfactual scenarios. Such an exercise assumes, of course, that the actual paths of the iron price premium, the U.K. price-cost margin, and the domestic market size (in terms of total expenditures) are unchanged and are independent of the tariff. While the iron price premium can be safely assumed to be exogenous, the U.K. price-cost margin and domestic market size could depend upon the tariff. ${ }^{19}$ The effect of this bias will be discussed below, although the results do not appear to be significantly affected because virtually identical results were obtained by using the estimated probit coefficients from the Table 3, column (1) regression, which includes only exogenous variables.

Four possible counterfactual scenarios are considered.

\section{A. No Erroneous Treasury Decision -}

Figure 7 (a) depicts the implied probability of domestic production under the supposition that the Treasury Department had imposed the 2-1/2 cent tariff on import tinplate from 1864 onward. The results suggest that this high initial tariff would not have been sufficient to bring about domestic production until 1872, when we observe entry even in the absence of this tariff. The iron bar price premium is apparently so great in the late 1860 s that even the higher tariff would not have been sufficient to make domestic production profitable. The higher tariff also

19 The great virtue of Head's (1994) counterfactual simulation of policies toward the steel rail industry is that the parameters of supply and demand are estimated jointly, treating prices and outputs as endogenous. The problem with his approach is that the counterfactual can be simulated only with great computational difficulty because there is no analytical solution to his supply and demand system. In addition, in the case of tinplate, the parameters of demand were poorly estimated. 
does not prevent the subsequent exit of domestic producers when tinplate prices collapsed in the mid-1870s, but postpones this exit for three years until 1878. However, the high tariff enables domestic production to commence again in 1883, eight years prior to the McKinley tariff. In sum, the higher tariff would have accelerated the entry of the domestic producers in the $1880 \mathrm{~s}$, but it neither would have assured the entry of domestic producers in the late 1860s-early 1870s nor would it have prevented their exit in the mid- to late-1870s.

\section{B. No McKinley Tariff -}

If the House had failed to pass the tinplate provision of the McKinley tariff, the 1 cent per pound tariff could have persisted for some time. This scenario allows us to examine the hypothesis that domestic entry would have occurred anyway as a result of the convergence in the price of iron bars. Figure 7 (b) shows the predicted probability of domestic production in this case. The probability repeatedly crosses the 50 percent line between $1898-1902$. After 1903 , the United States is virtually assured of having ongoing domestic production of tinplate. According to this result, if the McKinley tariff had not been enacted, a tinplate industry would have established itself in the United States about a decade later. The declining iron bar price premium, which was about 40 percent around 1890 but fell to 0-20 percent around 1900, largely accounts for this finding. This convergence in the prices of basic iron inputs is apparently sufficient to ensure that domestic production would eventually take place.

As previously noted, a possible problem with this counterfactual calculation is that the U.K. markup may be endogenously affected by the imposition of the McKinley duties. This possibility is not a certainty: with over 200 firms operating in Wales, declining sales could have been accommodated by the exit and consolidation of firms rather than falling markups. Indeed, 
Figure 2 suggests that the declining trend in the U.K. markup does not significantly accelerate after 1891, and Figure 1 depicts just a modest dip in the U.K. price around this time. To the extent that the markup actually did fall as a result of the McKinley duties, however, it biases the results against early entry by U.S. producers. In fact, performing this counterfactual with the Table 3, column (1) coefficients on the exogenous variables alone (the tariff and input price premium) suggests that U.S. firms would enter the market around 1895-97, slightly sooner than the above counterfactual predicted.

This simulation also might not capture the tariff's role in inducing the migration of labor and technology from Wales to the United States. As the early 1870 s experience demonstrates, however, a steep tariff hike was not required to attract Welsh skilled labor to America. U.S. entrepreneuers could freely recruit such labor and purchase specialized Welsh capital at any time. C. Zero Tinplate Tariff -

If tinplate imports had been placed on the duty-free list from 1869 onward, a brief period of domestic production would still have been observed in the early 1870 s, according to Figure 7 (c). However, the industry would not have established itself until about 1908, almost 20 years after the imposition of the McKinley duties.

D. No Iron Price Premium -

Had the United States allowed the free importation of iron bars at the U.K. price, Figure 7 (d) indicates that a domestic tinplate industry would have existed for most of the late nineteenth century. The possible lack of domestic iron production that this scenario might have entailed would not have posed a serious problem for tinplate producers. Vertical integration or domestic iron production was not a necessary condition for tinplate production. After the imposition of the 
McKinley tariff, for example, many U.S. producers imported "blackplate" — iron and steel sheets ready for dipping in tin — from the United Kingdom and performed the final production stage in America.

To summarize, the McKinley tariff clearly accelerated the development of the tinplate industry, according to these results, but the industry would have been established shortly thereafter anyway as the price of iron in the United States converged to that in the United Kingdom. The simulations illustrate the critical importance of material prices and the tariff compensated tinplate producers for the premium paid on iron inputs. Had there been no such premium, the United States might well have had a tinplate industry for most of the late nineteenth century.

The findings thus far suggest that the tinplate industry was not really an infant industry in the sense that new entrants faced particular hardships in overcoming a lack of production experience or in facing capital market imperfections (Andrew Carnegie was not liquidity constrained and could easily vertically integrate). Rather, the tinplate industry was laboring under extreme conditions of negative effective protection due to the high price of basic iron and steel products in the United States.

\section{Welfare Effects of Tinplate Protection}

Having found that the McKinley tariff enabled the United States to acquire a tinplate industry about a decade sooner that it otherwise would have arisen, the remaining question is whether this tariff policy was economically worthwhile.

The theory of optimal policy intervention provides a framework for assessing the welfare 
effects of the McKinley duties (Bhagwati 1971). The first-best policy toward the tinplate industry would be to remove the tariffs and other trade barriers that accounted for the high U.S. price of basic iron and steel products. This policy would have enabled the tinplate industry to function profitably throughout the late nineteenth century, as indicated by Figure 7 (d), and improved economic welfare. If the duties on basic iron and steel were considered immutable, the secondbest policy for the tinplate industry would have been to offset the distorted domestic price of iron and steel by subsidizing its use (perhaps through a rebate) by tinplate producers. The third-best policy would be a production subsidy to tinplate producers, which would also offset the distorted price of iron and steel, but less directly and therefore less efficiently. The fourth-best policy toward the tinplate industry would be a tariff on imported tinplate. A tariff would be akin to a production subsidy but even less efficient due to the by-product distortion to consumption. Though fourth-best, an optimally-set tinplate tariff would still be welfare improving vis-a-vis a policy of inaction.

To determine whether the McKinley tariff was near the optimal rate and was therefore beneficial, the initial costs to tinplate consumers as a result of the tariff must be more than compensated by the stream of profits received by domestic producers and tariff revenue received by the government (in a net present value sense). ${ }^{20}$ More formally, we can calculate the net welfare effects of infant industry protection as follows:

$$
\Delta \mathrm{W}_{\mathrm{t}}=\Delta \Pi_{\mathrm{t}}+\Delta \mathrm{CS}_{\mathrm{t}}+\Delta \tau \mathrm{M}_{\mathrm{t}}
$$

where the change in welfare $\mathrm{W}$ is decomposed into the change in producer profits $\Pi$, the change

${ }^{20}$ We can treat the tinplate industry in partial equilibrium since it had a negligible effect on the output of the iron and steel industry overall; in 1899, the tinplate industry consumed 36,855 tons of iron and steel when 29,507,860 tons were produced (Gray 1902, pp. 101, 4). 
in consumers's surplus CS, and the change in tariff revenue $\tau \mathrm{M}$. The stream of profits received by domestic producers, however, should be calculated using the world price of iron and steel (the true opportunity cost, and therefore the true shadow price), as suggested in the project evaluation literature (Corden 1974, pp. 389ff). The tariff is economically beneficial if the present discounted value of the change in welfare is positive:

$$
\mathrm{PV}(\mathrm{r})=\Sigma \Delta \mathrm{W}_{\mathrm{t}} /(1+\mathrm{r})^{\mathrm{t}}>0
$$

where $r$ is the real interest rate.

In performing this calculation, the actual McKinley and subsequent tariffs imposed on imported tinplate will be evaluated against the counterfactual benchmark of maintaining the preexisting 1 cent per pound tariff on imported tinplate. The path of output and prices under the McKinley and subsequent tariffs is observed, and therefore we are required to speculate as to what would have happened to each of the components of welfare had the existing duty continued in force up to a specified time horizon. That horizon will be taken as the year 1900: If the object of the tariff policy was merely to establish some domestic tinplate production, without specifying the precise amount, then the Section IV simulations suggest that production would have commenced sometime around 1895-1902, in the absence of the McKinley tariff.

For $\Delta \Pi$, the actual profits received by domestic producers can be compared with zero profits (presuming there being no domestic production) over this horizon. Census of Manufacturing data indicate that the ratio of average costs to price $\left(\mathrm{AC} / \mathrm{P}_{\mathrm{US}}\right)$ was 0.90 in 1899 (Gray 1902, p. 100), but this measures profits using the domestic price of iron inputs rather than the (shadow) import price. This measure needs to be adjusted a factor $\phi$ that represents by the degree to which costs would have been lower had the import price been used. Rather than 0.90, 
the term $\phi \mathrm{AC} / \mathrm{P}_{\mathrm{US}}$ is about 0.7 in the early $1890 \mathrm{~s}$, about 0.8 in the mid- $1890 \mathrm{~s}$, and about 0.9 by the turn of the century, tracking the declining iron price premium shown on Figure 5. Thus, $\Delta \Pi$ $=\left(1-\left[\phi A C / \mathrm{P}_{U S}\right]\right) \mathrm{P}_{U S} \mathrm{Q}_{U S}-0$, where $\mathrm{P}_{\mathrm{US}} \mathrm{Q}_{\mathrm{US}}$ is the actual value of domestic tinplate sold.

The consumers's surplus calculation is simply the price wedge over all purchases under the McKinley tariff regime (note that the second-order deadweight loss will not be included in this calculation). Thus, $\Delta \mathrm{CS}=\left(\mathrm{P}_{\mathrm{US}} \mathrm{Q}_{\mathrm{US}}+\left[\mathrm{P}_{\mathrm{UK}}+\tau\right] \mathrm{M}\right)-\left(\left[\mathrm{P}_{\mathrm{UK}}{ }^{\prime}+1\right]\left[\mathrm{Q}_{\mathrm{US}}+\mathrm{M}\right]\right)$, where the first term in parenthesis is the cost to consumers of their actual observed purchases and the second term is the cost of that same quantity of tinplate had they been able to purchase it from the United Kingdom under the 1 cent duty. The latter cost depends upon $\mathrm{P}^{\mathrm{UK} \prime}$, the (counterfactual) price of U.K. tinplate in the absence of the McKinley duties. Two counterfactual prices are considered: the actual price, which may have been lower due to the McKinley tariff, and the out-of-sample forecasted price based on estimating the equivalent of the markup equation from Table 2 using U.K. data. This forecasted U.K. tinplate price is, on average, slightly higher than the actual price: The average actual price is $\$ 2.65$ per hundred pounds over $1891-1900$, whereas the forecasted price is $\$ 2.95$ per hundred pounds. Because U.S. tinplate prices quickly fall to almost those prevailing in the United Kingdom, there is the possibility that the consumer surplus calculation will be positive, particularly in comparison with the higher forecasted U.K. price.

The final component is tariff revenue, calculated as $\Delta \tau \mathrm{M}=\tau \mathrm{M}-1^{*}\left(\mathrm{M}^{\prime}\right)$. The amount of tariff revenue raised under a 1 cent per pound tariff regime depends upon the counterfactual volume of imports, $\mathbf{M}^{\prime}$. This counterfactual import volume was projected by a logarithmic autoregressive trend extrapolation estimated over 1869-1890. This projection implies an average annual import growth of 6.6 percent and yields a trend very similar to that of total consumption 
after 1890 in Figure 4 but at a slightly higher level.

These welfare calculations should be viewed as a simple back-of-the-envelope calculation as to the possible impact of the tariff over the $1891-1900$ period because they are not based on a fully specified counterfactual simulation (see note 20). Table 4 presents the results for two real interest rates and for two calculations of the counterfactual U.K. price. The findings are uniformly negative for the McKinley tariff: the initial large loss of consumer surplus (and eventually tariff revenue) is not offset by the stream of profits received by domestic producers evaluated using the import price of iron bar. Tinplate production does not generate large profits because it is a relatively easy entry, low margin business, and the import price of iron bars does not remain significantly below the U.S. price for long (when the import price of iron is significantly below the U.S. price, domestic output and profits are small; by the end of the century when output and profits are higher, the shadow price is about equivalent to the U.S. price). The change in tariff revenue starts highly positive, as import volume does not decline much initially when the higher duty is imposed, but imports rapidly shrink with time and thereby generate large revenue losses for the government.

The change in consumer surplus actually becomes positive by the late 1890s when U.S. prices fall below the higher forecasted U.K. prices, which explains why the welfare losses diminish over the longer horizon. But this later gain does not compensate for the initial consumer losses. If actual prices are taken as the relevant counterfactual, then the McKinley tariff has a harder time paying off because these U.K. prices remain low through the 1890s.

To conclude, U.S. economic welfare could have been enhanced by an optimally-set fourthbest tariff to offset the distorted price of iron bars faced by domestic tinplate producers. 
However, in a period when the domestic price of iron bars was rapidly converging to the import price, the McKinley tariff appears to have been set too high and thus more than compensated for the input price distortion. A tariff of the McKinley tariff's height may have been more suitable for the 1870 s and 1880 s when the domestic price premium on iron and steel was substantially higher than it was in the $1890 \mathrm{~s}^{21}$

\section{Concluding Comments}

This paper posed two questions regarding infant industry protection for the tinplate industry: When (if ever) would the industry have developed in the absence of protection? Were tariffs economically worthwhile in establishing domestic production sooner than it otherwise would have occurred? At first glance, the tinplate industry appears to be a successful instance of infant industry protection. Upon further examination, the industry is revealed to be one in which material input costs are paramount, static and dynamic scale economies are not substantial, and production technology and experience is readily transferable internationally. The analysis here suggests that the tinplate industry would have developed in the United States within a decade of the McKinley tariff, as the domestic price of iron and steel inputs converged to international levels. While a optimally-set tariff would have been a fourth-best but welfare-improving method of correcting the distorted domestic price of iron faced by tinplate producers, the McKinley tariff was set too high, more than offset that distortion, and thus failed to improve welfare.

${ }^{21}$ For example, using the simple formula for the effective rate of protection and data in footnote 15 , a 50 percent tariff on tinplate would have yielded an effective rate of zero, completely offsetting the iron bar tariff. If the iron bar tariff fell to 10 percent, then only a 7 percent tinplate tariff would have been necessary to yield an effective rate of zero. 
Table 1: Spearman Rank Correlations of U.S. Tariffs and Industry Performance, c.1899.

Nominal and effective tariff data are from 1899. Industry performance variables are their growth between 18991909. ERP-A is the calculated effective rate when the underlying data are assumed to reflect the no-tariff equilibrium, ERP-B to reflect the tariff-inclusive equilibrium; calculated according to the formula in Corden (1971), pp. 35-37. Number of industry observations in parenthesis.

$\begin{array}{ccc} & \text { Effective Rate of } & \text { Effective Rate of } \\ \text { Nominal Tariff } & \text { Protection (A) } & \text { Protection (B) }\end{array}$

\begin{tabular}{|c|c|c|c|}
\hline Nominal Tariff & $\begin{array}{l}1.00 \\
(20)\end{array}$ & $\begin{array}{c}0.45 \\
(15) \\
\mathrm{p}=0.10\end{array}$ & $\begin{array}{c}0.80 \\
(15) \\
\mathrm{p}=0.00\end{array}$ \\
\hline $\begin{array}{l}\text { Effective Rate } \\
\text { of Protection (A) }\end{array}$ & -- & $\begin{array}{l}1.00 \\
(15)\end{array}$ & $\begin{array}{c}0.79 \\
(15) \\
\mathrm{p}=0.00\end{array}$ \\
\hline $\begin{array}{l}\text { Effective Rate } \\
\text { of Protection (B) }\end{array}$ & -- & -- & $\begin{array}{l}1.00 \\
(15)\end{array}$ \\
\hline$\Delta$ Total Factor Productivity & $\begin{array}{c}0.17 \\
(20) \\
\mathrm{p}=0.47\end{array}$ & $\begin{array}{c}0.50 \\
(15) \\
\mathrm{p}=0.06\end{array}$ & $\begin{array}{c}0.27 \\
(15) \\
\mathrm{p}=0.33\end{array}$ \\
\hline$\Delta$ Output & $\begin{array}{c}-0.31 \\
(15) \\
\mathrm{p}=0.27\end{array}$ & $\begin{array}{c}0.35 \\
(14) \\
\mathrm{p}=0.22\end{array}$ & $\begin{array}{c}-0.01 \\
(14) \\
\mathrm{p}=0.97\end{array}$ \\
\hline$\Delta$ Labor Productivity & $\begin{array}{c}-0.11 \\
(15) \\
\mathrm{p}=0.68\end{array}$ & $\begin{array}{c}0.47 \\
(14) \\
\mathrm{p}=0.09\end{array}$ & $\begin{array}{c}0.22 \\
(14) \\
\mathrm{p}=0.45\end{array}$ \\
\hline$\Delta$ Capital Accumulation & $\begin{array}{c}-0.18 \\
(15) \\
\mathrm{p}=0.52\end{array}$ & $\begin{array}{c}-0.14 \\
(14) \\
\mathrm{p}=0.63\end{array}$ & $\begin{array}{c}-0.01 \\
(14) \\
\mathrm{p}=0.96\end{array}$ \\
\hline
\end{tabular}

Data Sources: total factor productivity, output growth, labor productivity, capital accumulation, all from Kendrick (1960), Table D-IV. Nominal tariff data: author's calculations based on U.S. Foreign Trade and Navigation (1900). Effective rates of protection: author's calculation based on U.S. input-output table for 1899 in Whitney (1968). Sectors include: food and kindred products, beverages, textile mill products, apparel and related products, lumber and products, furniture and fixtures, paper and allied products, chemicals and allied products, rubber products, leather and products, stone, clay, and glass products, primary metals industry, fabricated metal industries, nonelectrical machinery, electrical machinery, transportation equipment, and miscellaneous and instruments. 
Table 2: Estimates of Tinplate Production Costs.

The dependent variable is the U.S. price of tinplate. Estimation methods: nonlinear least squares (NLS), log-linear least squares (LLS). Standard errors, corrected for heteroskedasticity, in parenthesis. For the period 1869-1913, zero values of current output have been set equal to one. Instruments include the ad valorem U.S. tariff, the sterling-dollar exchange rate, domestic expenditures on tinplate, and include all U.S. and U.K. independent variables.

\begin{tabular}{|c|c|c|c|c|c|c|c|}
\hline & $\begin{array}{l}(1) \\
\text { NLS }\end{array}$ & $\begin{array}{l}(2) \\
\text { NLS }\end{array}$ & $\begin{array}{l}(3) \\
\text { LLS }\end{array}$ & $\begin{array}{l}(4) \\
\text { LLS }\end{array}$ & $\begin{array}{l}(5) \\
\text { LLS }\end{array}$ & $\begin{array}{l}\text { (6) } \\
\text { LLS }\end{array}$ & $\begin{array}{c}(7) \\
\text { U.K. Data } \\
\text { NLS }\end{array}$ \\
\hline $\begin{array}{l}\alpha \\
\text { (constant) }\end{array}$ & $\begin{array}{l}186.63 \\
(291.81)\end{array}$ & $\begin{array}{l}5724.55 \\
(9113.29)\end{array}$ & $\begin{array}{c}11.86 \\
(44.36)\end{array}$ & $\begin{array}{c}94.87 \\
(45.15)\end{array}$ & $\begin{array}{c}2.09 \\
(1.61)\end{array}$ & $\begin{array}{c}3.03 \\
(1.70)\end{array}$ & $\begin{array}{c}4.44 \\
(1.96)\end{array}$ \\
\hline $\begin{array}{l}\beta \\
\text { (price of iron bars) }\end{array}$ & $\begin{array}{c}0.62 \\
(0.12)\end{array}$ & $\begin{array}{c}0.58 \\
(0.10)\end{array}$ & $\begin{array}{c}0.38 \\
(0.10)\end{array}$ & $\begin{array}{c}0.33 \\
(0.12)\end{array}$ & $\begin{array}{c}0.51 \\
(0.12)\end{array}$ & $\begin{array}{c}0.51 \\
(0.11)\end{array}$ & $\begin{array}{c}0.51 \\
(0.10)\end{array}$ \\
\hline $\begin{array}{l}\gamma \\
\text { (current output) }\end{array}$ & $\begin{array}{c}0.04 \\
(0.01)\end{array}$ & $\begin{array}{c}0.06 \\
(0.02)\end{array}$ & $\begin{array}{l}-0.41 \\
(0.12)\end{array}$ & $\begin{array}{l}-0.15 \\
(0.20)\end{array}$ & $\begin{array}{c}0.03 \\
(0.01)\end{array}$ & $\begin{array}{c}0.05 \\
(0.02)\end{array}$ & $\begin{array}{l}-0.10 \\
(0.06)\end{array}$ \\
\hline $\begin{array}{l}\lambda \\
\text { (experience) }\end{array}$ & $\begin{array}{l}-0.03 \\
(0.01)\end{array}$ & $\begin{array}{l}-0.04 \\
(0.02)\end{array}$ & $\begin{array}{c}0.12 \\
(0.02)\end{array}$ & $\begin{array}{c}0.08 \\
(0.05)\end{array}$ & $\begin{array}{l}-0.02 \\
(0.01)\end{array}$ & $\begin{array}{l}-0.04 \\
(0.02)\end{array}$ & $\begin{array}{l}-0.09 \\
(0.15)\end{array}$ \\
\hline $\begin{array}{l}\theta \\
\text { (weight on UK experience) }\end{array}$ & $\begin{array}{c}8.22 \\
(4.23)\end{array}$ & $\begin{array}{l}11.26 \\
(6.14)\end{array}$ & $\begin{array}{l}-2.90 \\
(20.69)\end{array}$ & $\begin{array}{l}-67.87 \\
(73.87)\end{array}$ & $\begin{array}{c}1.88 \\
(4.07)\end{array}$ & $\begin{array}{l}2.50 \\
(2.22)\end{array}$ & -- \\
\hline $\begin{array}{l}\mu \\
\text { (time trend) }\end{array}$ & $\begin{array}{c}0.09 \\
(0.09) \\
\end{array}$ & $\begin{array}{c}0.22 \\
(0.76) \\
\end{array}$ & $\begin{array}{c}0.01 \\
(0.10) \\
\end{array}$ & $\begin{array}{c}0.20 \\
(0.10) \\
\end{array}$ & $\begin{array}{l}-0.02 \\
(0.01) \\
\end{array}$ & $\begin{array}{l}-0.01 \\
(0.01) \\
\end{array}$ & $\begin{array}{l}-0.01 \\
(0.01) \\
\end{array}$ \\
\hline Adj. $R^{2}$ & 0.91 & 0.91 & 0.84 & 0.85 & 0.90 & 0.90 & 0.89 \\
\hline Instruments & No & Yes & No & Yes & No & Yes & Yes \\
\hline Time Period & $1869-1913$ & $1869-1913$ & 1891-1913 & 1891-1913 & $1869-1913$ & $1869-1913$ & $1869-1913$ \\
\hline
\end{tabular}

Data Sources: U.S. prices: from 1869-1890, New York prices in U.S. House of Representatives (1892), Appendix E, p. 7. From 1891-1913, Dunbar (1915), p. 75. U.S. production: Statistical Abstract of the United States, various issues (1900-1916). U.K. prices: the U.S. import price, Statistical Abstract of the United States, various issues (1900-1916). U.K. exports to U.S.: Statistical Abstract of the United States, various issues (1900-1916). U.K. production: Brooke (1944), Appendix pp. 1-3. Iron: U.S. price: refined rolled bar iron (Philadelphia) from the Statistical Abstract of the United States (1916), p. 520. U.K. price: common iron bars, from Mitchell (1988), p. 763. Exchange Rate: Mitchell (1988), p. 702. Import Duty: U.S. House of Representatives (1909). 
Table 3: Determinants of the Decision to Produce Tinplate in the United States: Marginal Effects from Probit Regression, 1869-1913.

The dependent variable takes the value of 1 for the years 1872-1875 and 1891-1913, and is zero otherwise. Number of observations is 45 . Robust standard errors are in parenthesis. Pseudo- $\mathrm{R}^{2}$ is defined as ( 1 $\mathrm{L}_{1} / \mathrm{L}_{0}$ ), where $\mathrm{L}_{1}$ is the value of the log-likelihood function including the independent variables and $\mathrm{L}_{0}$ is its value including just a constant term.

\begin{tabular}{lccc} 
Independent Variable & $(1)$ & $(2)$ & $(3)$ \\
Ad Valorem Tariff & & & 1.97 \\
Equivalent & $(0.61)$ & $(1.70)$ & $(0.94)$ \\
Iron Bar Price Differential & -0.83 & -1.30 & -1.34 \\
& $(0.40)$ & $(0.37)$ & $(0.37)$ \\
& & & 1.15 \\
U.K. Price-Bar Cost Margin & -- & 0.48 & $(0.21)$ \\
& & $(0.19)$ & 1.11 \\
Log of Domestic Market & & & $(0.21)$ \\
Size & -- & -- & 0.71 \\
\hline Pseudo R & & & $95.6 \%$ \\
Percent Correctly Predicted & & & \\
\hline
\end{tabular}


Table 4: Welfare Effects of the McKinley Tinplate Tariff.

Basis of Comparison: Imposing the McKinley tariff vis-a-vis the existing 1 cent per pound tariff. Figures are calculation of $\mathrm{PV}(\mathrm{r})=\Sigma \Delta \mathrm{W}_{\mathrm{t}} /(1+\mathrm{r})^{\mathrm{t}}$, where $\Delta \mathrm{W}_{\mathrm{t}}=\Delta \Pi_{\mathrm{t}}+\Delta \mathrm{CS}_{\mathrm{t}}+\Delta \tau \mathrm{M}_{\mathrm{t}}$ as described in the text. All figures are in millions of 1891 dollars, having been deflated by the consumer price index in David and Solar (1977), p. 16.

A. Using Forecasted (Counterfactual) U.K. Prices

\begin{tabular}{ccc} 
Time Horizon\Discount Rate & $\mathrm{r}=0.06$ & $\mathrm{r}=0.03$ \\
$1891-1895$ & $-\$ 12.4 \mathrm{~m}$ & $-\$ 13.2 \mathrm{~m}$ \\
$1891-1897$ & $-\$ 14.5 \mathrm{~m}$ & $-\$ 15.5 \mathrm{~m}$ \\
$1891-1900$ & $-\$ 11.3 \mathrm{~m}$ & $-\$ 9.9 \mathrm{~m}$ \\
\hline
\end{tabular}

B. Using Actual U.K. Prices

Time Horizon\Discount Rate

$r=0.06$

$r=0.03$

$1891-1895$

$-\$ 8.2 \mathrm{~m}$

$-\$ 9.5 \mathrm{~m}$

$1891-1897$

$-\$ 15.1 \mathrm{~m}$

$-\$ 17.1 \mathrm{~m}$

$1891-1900$

$-\$ 25.6 m$

$-\$ 30.4 \mathrm{~m}$ 


\section{References}

Ayers, Ian. "The Tin Plate Industry in the United States." Journal of the Franklin Institute 143 (June 1897): 424-446.

Berglund, Abraham, and Philip G. Wright. The Tariff on Iron and Steel. Washington, D.C.: The Brookings Institution, 1929.

Berthoff, Rowland T. British Immigrants to Industrial America, 1750-1950. Cambridge: Harvard University Press, 1953.

Bhagwati, Jagdish. "The Generalized Theory of Distortions and Welfare." In J. Bhagwati, R. Mundell, R. Jones, and J. Vanek (eds.), Trade, Balance of Payments and Growth. Amsterdam: North-Holland, 1971.

Clark, Victor S. History of Manufactures in the United States. 3 vols. New York: McGraw-Hill for the Carnegie Institute, 1929.

Corden, W. M. The Theory of Protection. Oxford: Oxford University Press, 1971.

Corden, W. M. Trade Policy and Economic Welfare. Oxford: Clarendon Press, 1974.

Cronemeyer, W. C. "The Development of the Tin-Plate Industry." Western Pennsylvania Historical Magazine 13 (1931): 23-54, 123-135.

David, Paul. "Learning by Doing and Tariff Protection: A Reconsideration of the Case of the Ante-Bellum United States Cotton Textile Industry." Journal of Economic History 30 (September 1970): 521-601.

David, Paul, and Peter Solar. "A Bicentenary Contribution to the History of the Cost of Living in America," in Research in Economic History. Greenwich, CT: JAI Press, 1977.

Dunbar, D. E. The Tin-Plate Industry. Boston: Houghton Mifflin Co., 1915.

Gray, William G. "Tin and Terne Plate." Census Reports, Vol. X. Manufactures. Pt. IV. Special Reports on Selected Industries. Washington, D.C.: U.S. Census Office, 1902.

Harrison, Ann E. “An Empirical Test of the Infant Industry Argument: Comment." American Economic Review 84 (September 1994): 1090-1095.

Hawke, G. R. "The United States Tariff and Industrial Protection in the Late Nineteenth Century." Economic History Review 28 (February 1975): 84-99. 
Head, Keith. "Infant Industry Protection in the Steel Rail Industry." Journal of International Economics 37 (November 1994): 141-165.

Hogan, William T. Economic History of the Iron and Steel Industry in the United States. 2 vols., Lexington, MA: D.C. Heath \& Co., 1971.

Hyde, Charles K. "Iron and Steel Technologies Moving Between Europe and the United States Before 1914." In David J. Jeremy (ed.), International Technology Transfer: Europe, Japan, USA, 1700-1914. Aldershot: Edward Elgar, 1991.

Irwin, Douglas A. Against the Tide: An Intellectual History of Free Trade. Princeton: Princeton University Press, 1996.

Irwin, Douglas A., and Peter J. Klenow. "Learning-by-Doing Spillovers in the Semiconductor Industry." Journal of Political Economy 102 (December 1994): 1200-1227.

Kendrick, John. Productivity Trends in the United States. Princeton: Princeton University Press for the NBER, 1960.

Knox, Howard A. Development of the American Tin Plate Industry. Pittsburgh: Carnegie-Illinois Steel Corp., n.d.

Krueger, Anne O., and Baran Tuncer. "An Empirical Test of the Infant Industry Argument." American Economic Review 72 (December 1982): 1142-1152.

Krueger, Anne O., and Baran Tuncer. "An Empirical Test of the Infant Industry Argument: Reply." American Economic Review 84 (September 1994): 1096.

Minchinton, W. E. The British Tinplate Industry. Oxford: Clarendon Press, 1957.

Mitchell, B. R. British Historical Statistics. New York: Cambridge University Press, 1988.

Poirier, Dale J., and Paul A. Ruud. "Probit with Dependent Observations." Review of Economic Studies 55 (October 1955): 593-614.

Stanwood, Edward. American Tariff Controversies in the Nineteenth Century. Boston: Houghton, Mifflin \& Co., 1903.

Tariff Commission. Report of the Tariff Commission. 2 vols. Washington, D.C.: Government Printing Office, 1883.

Taussig, Frank W. Some Aspects of the Tariff Question. Cambridge: Harvard University Press, 1915. 
Tedesco, Paul H. Patriotism, Protection, and Prosperity: James Moore Swank, the American Iron and Steel Association, and the Tariff: 1873-1913. New York: Garland Publishing, 1985.

Temin, Peter. Iron and Steel in Nineteenth Century America: An Economic Inquiry. Cambridge: MIT Press, 1964.

U.S. Department of Treasury, Bureau of Statistics. Foreign Commerce and Navigation of the United States, 1899. Washington, D.C.: Government Printing Office, 1900.

U.S. Department of Treasury, Bureau of Statistics. Statistical Abstract of the United States. Washington, D.C.: Government Printing Office, various years, 1900-16.

U.S. House of Representatives. Revision of the Tariff. House Miscellaneous Document No. 176, 51 ${ }^{\text {st }}$ Congress, $1^{\text {st }}$ Session. Washington: Government Printing Office, 1890.

U.S. House of Representatives. Revision of the Tariff. House Report No. 1040, $52^{\text {st }}$ Congress, $1^{\text {st }}$ Session. Washington: Government Printing Office, 1892.

U.S. House of Representatives. Tariff Acts Passed by the Congress of the United States from 1789 to 1909 . House Document $671,61^{\text {st }}$ Congress, $2 \mathrm{~d}$ Session. Washington: Government Printing Office, 1909.

Whitney, William G. "The Structure of the American Economy in the Late Nineteenth Century." Department of Economics Discussion Paper No. 80, University of Pennsylvania, 1968.

Williamson, Jeffrey G. "Embodiment, Disembodiment, Learning by Doing, and Returns to Scale in Nineteenth Century Cotton Textiles." Journal of Economic History 31 (September 1972): 691-705.

Wright, Gavin. "The Origins of American Industrial Success, 1879-1940.” American Economic Review 80 (September 1990): 651-668. 


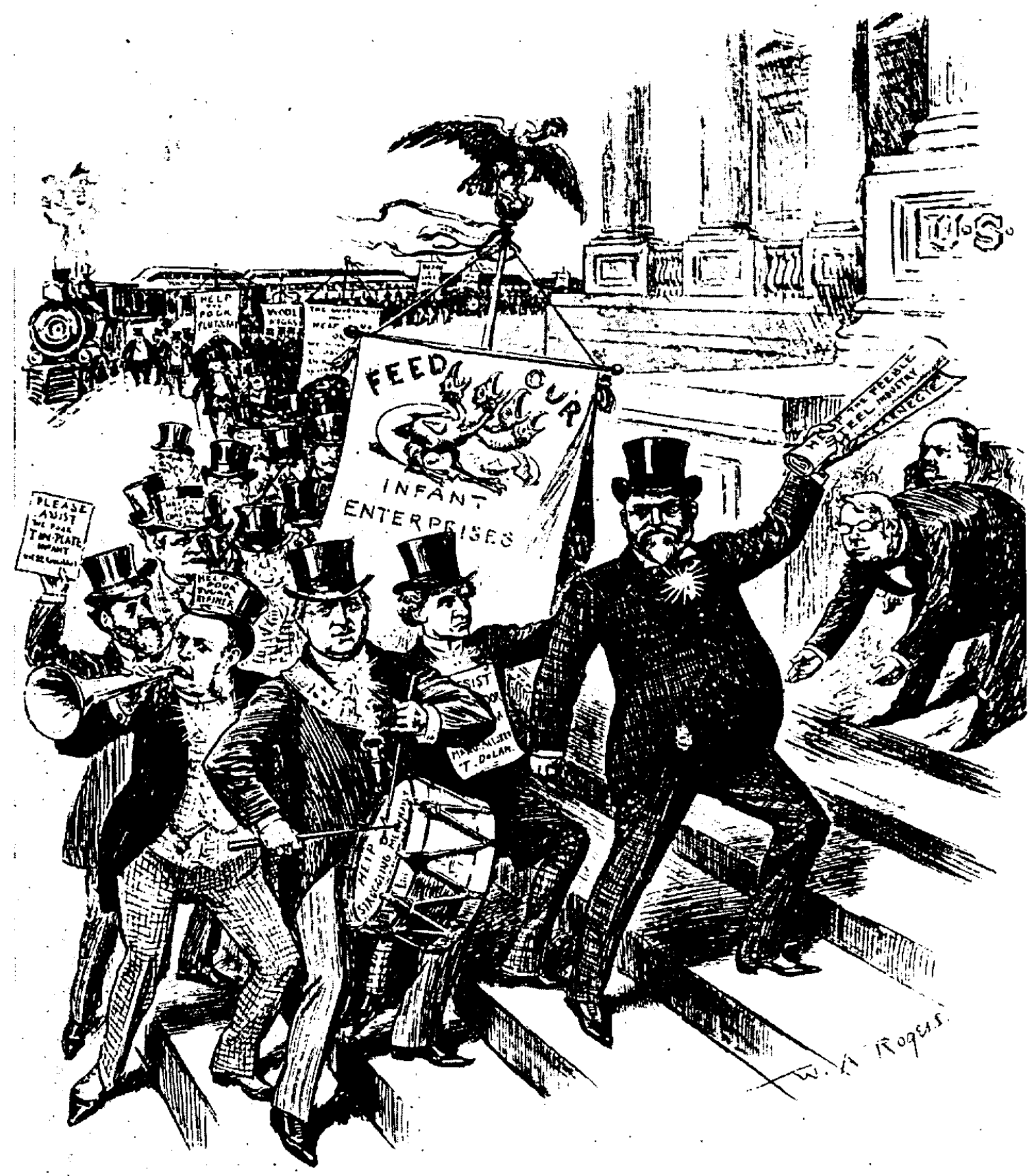

Business Seeks Aid from the Nation

A cartoon from Harper's in May 1894 depicting representatives from "infant industries" lining up on the steps of the U.S. Congress. Note the tinplate representative at the far left. 


\section{FIGURE 1}

\section{Tinplate Prices}

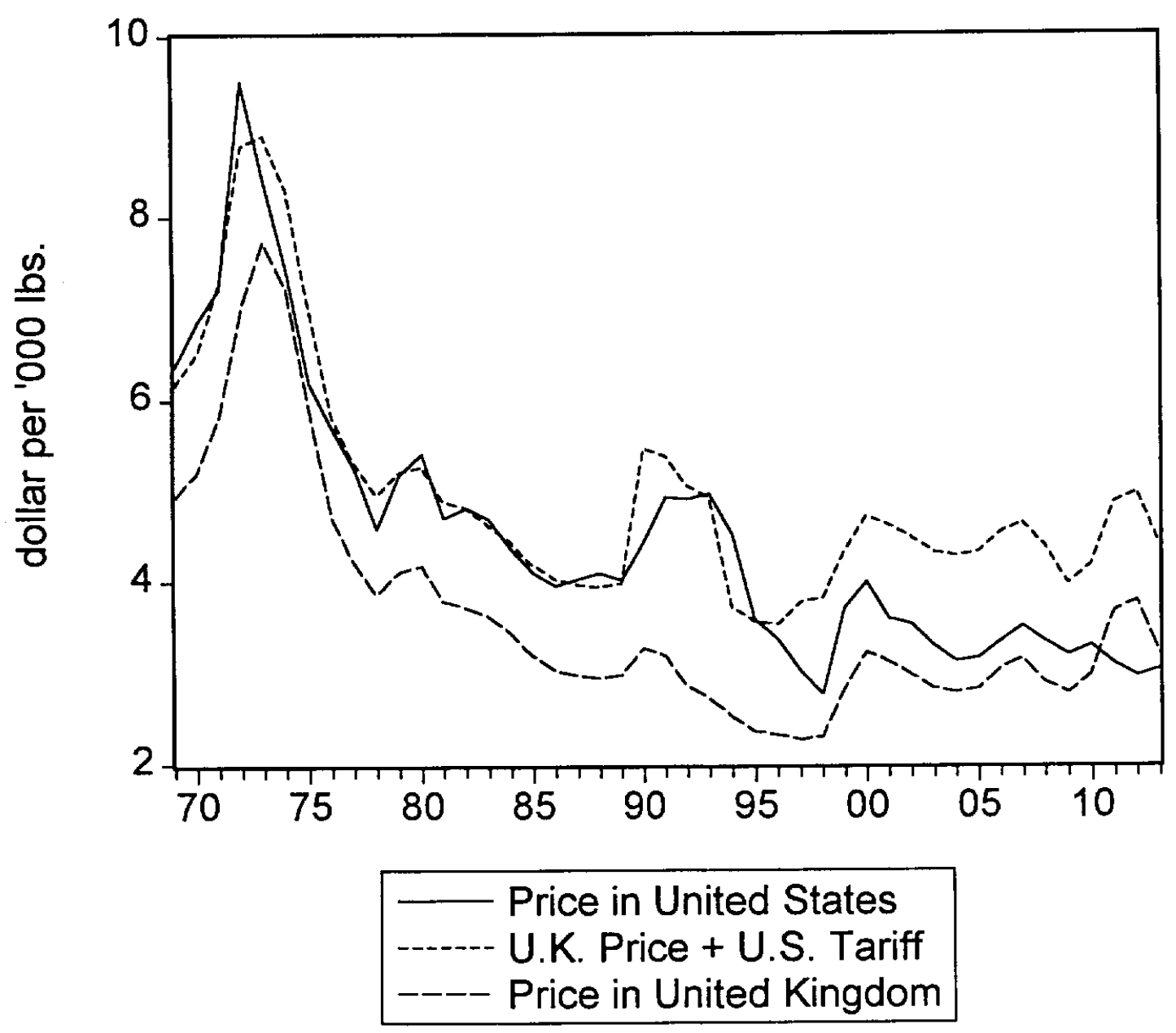


FIGURE 2

Tinplate Price-Iron Bar Cost Margin for UK Producers

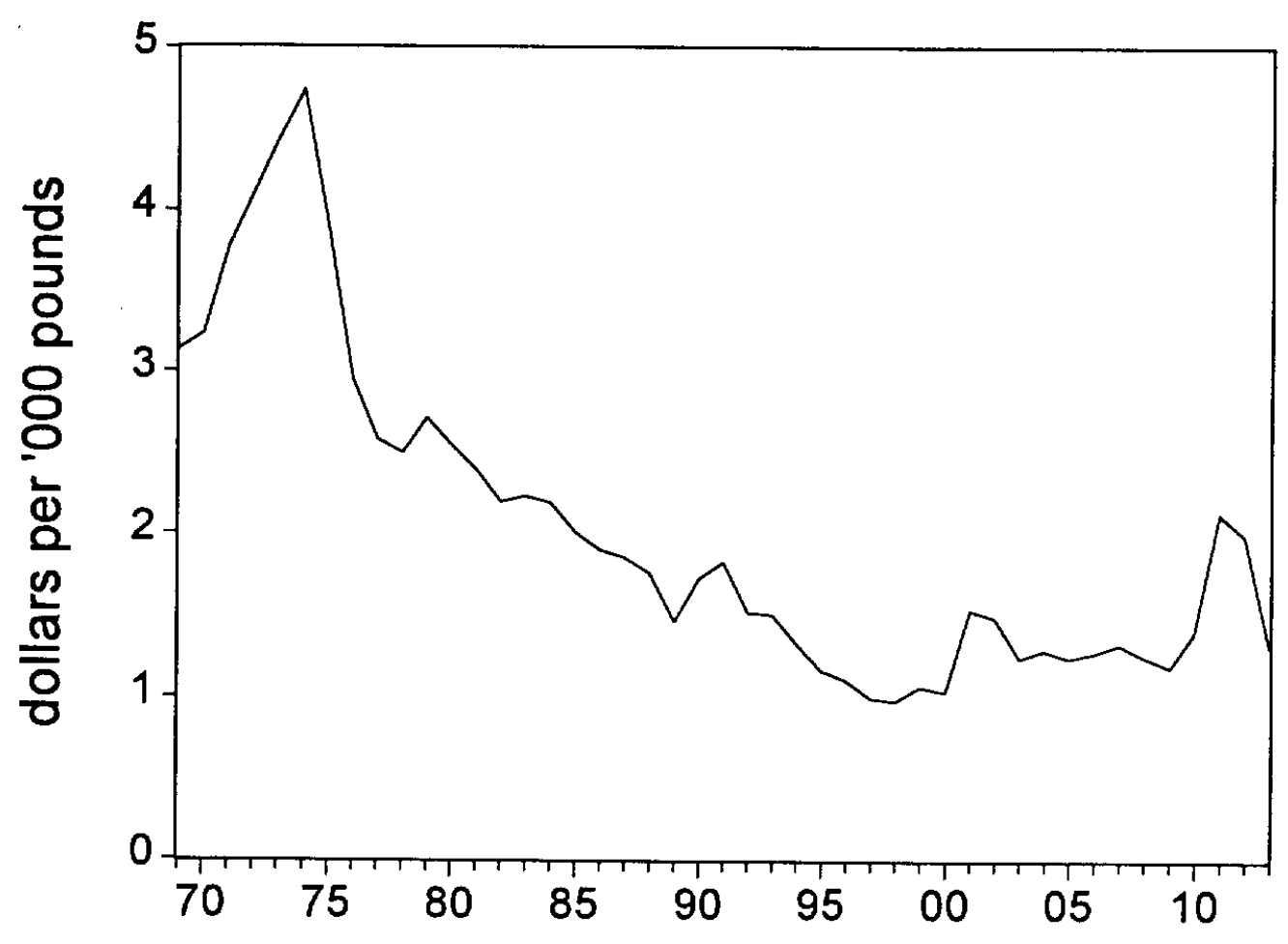

Year 
FIGURE 3

Tariff on U.S. Tinplate Imports

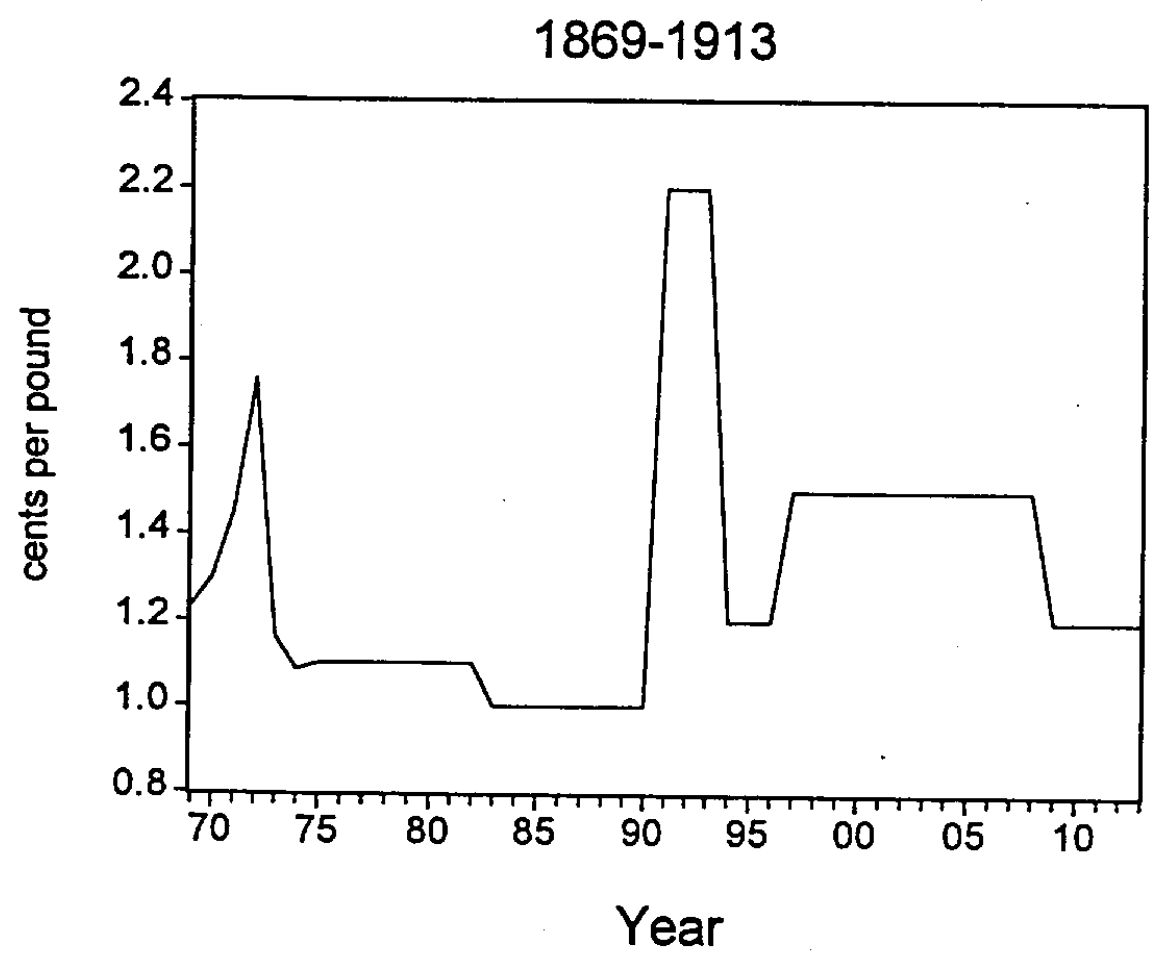

Tariff on U.S. Tinplate Imports 1869-1913

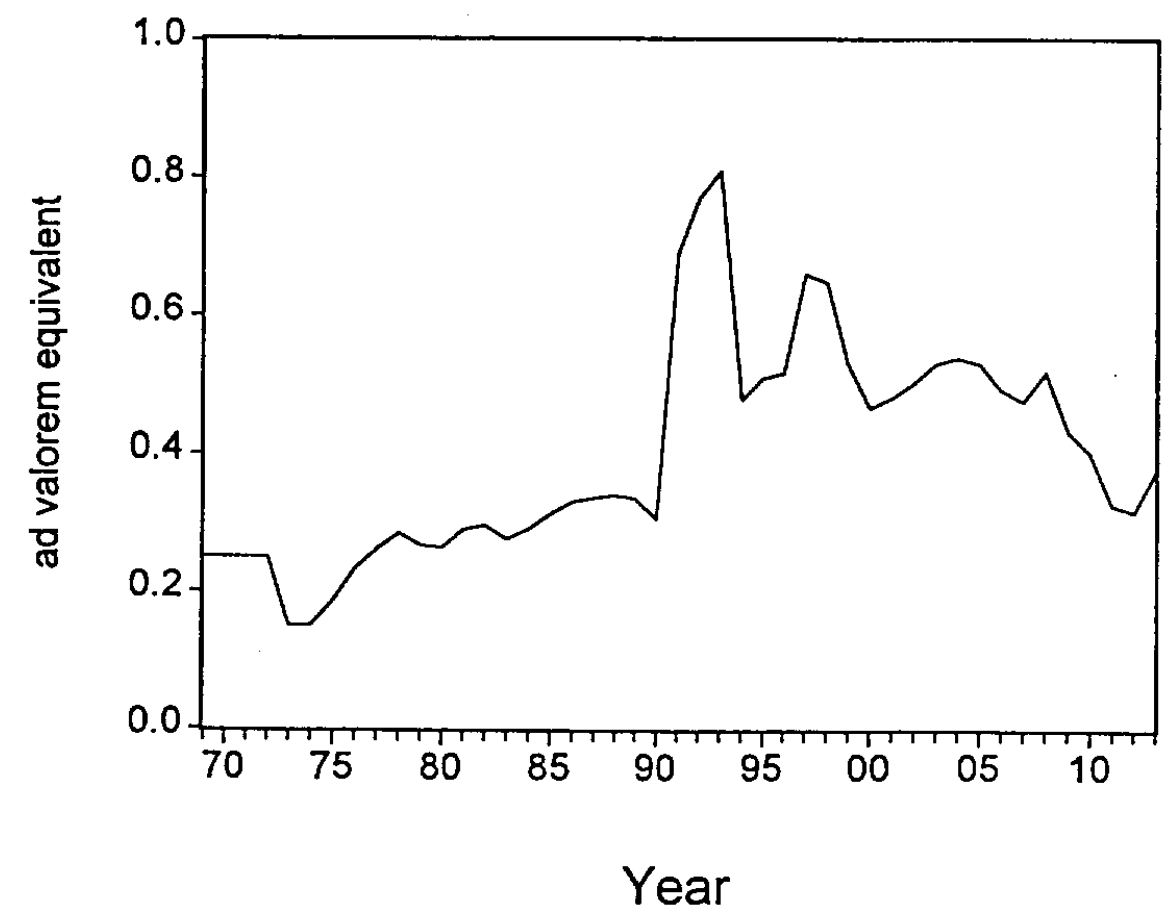


FIGURE 4

Total U.S. Tinplate Consumption

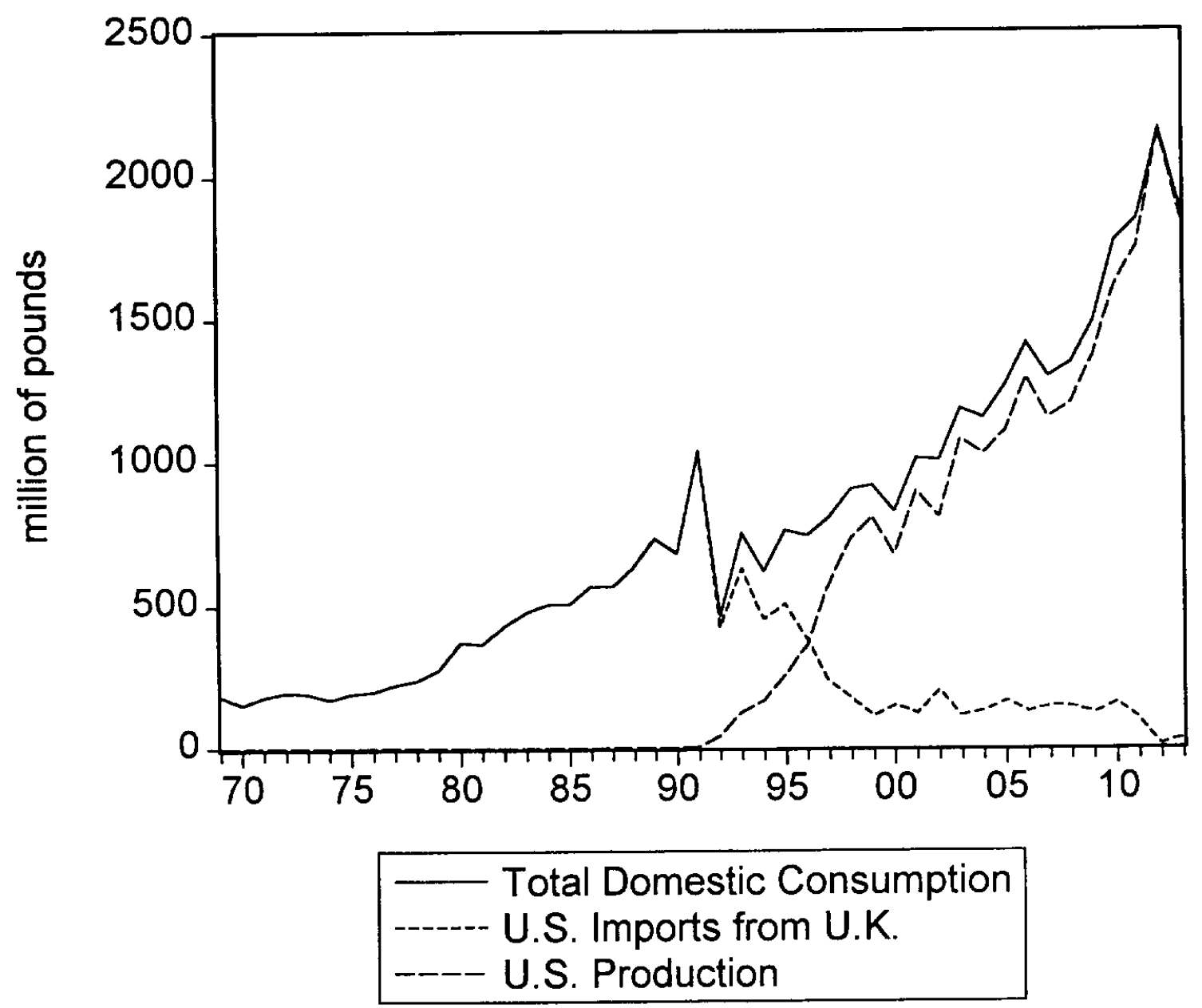


FIGURE 5

\section{Iron Bar Price Premium in the United States}

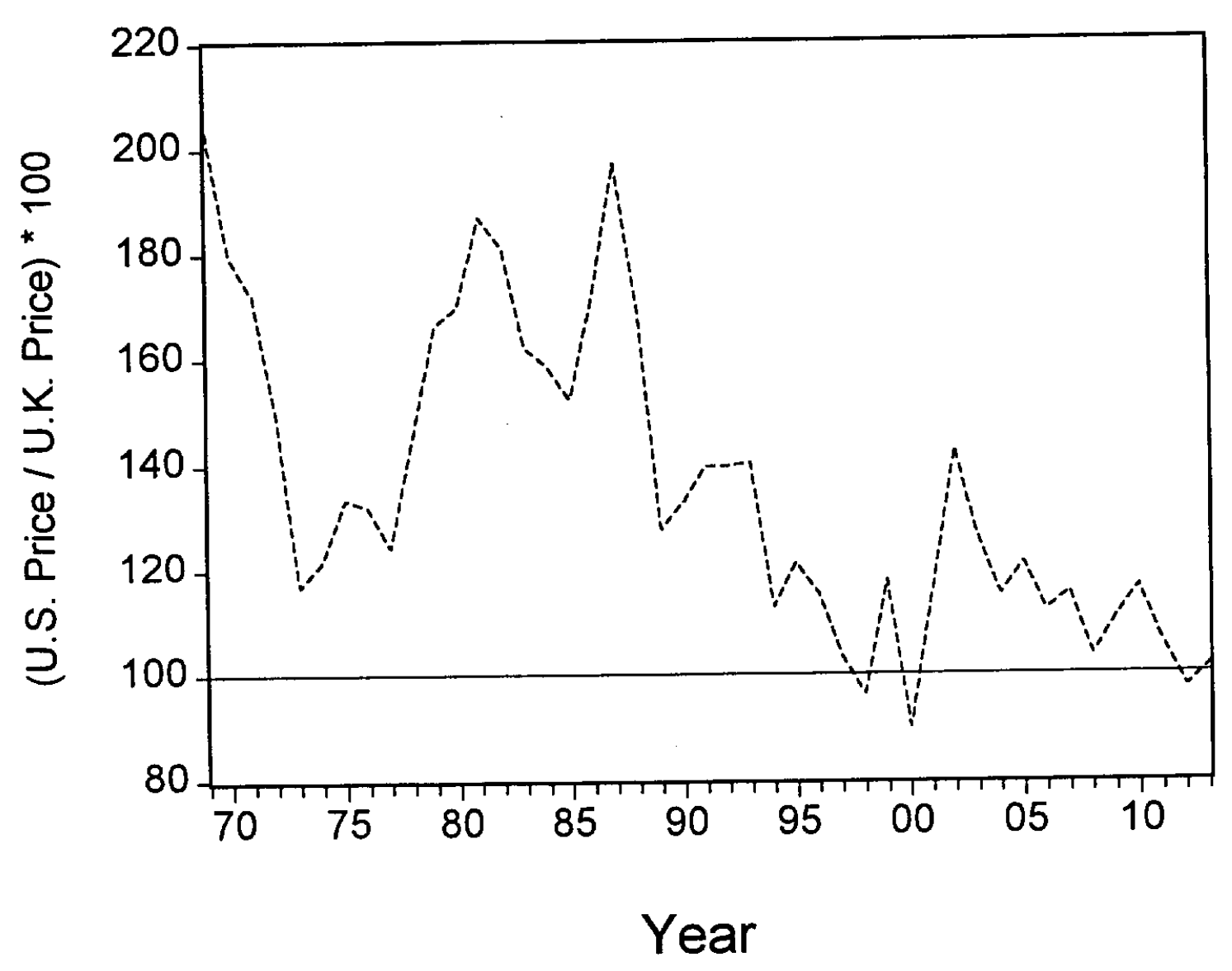


FIGURE 6

Predicted Probability of Domestic Tinplate Production

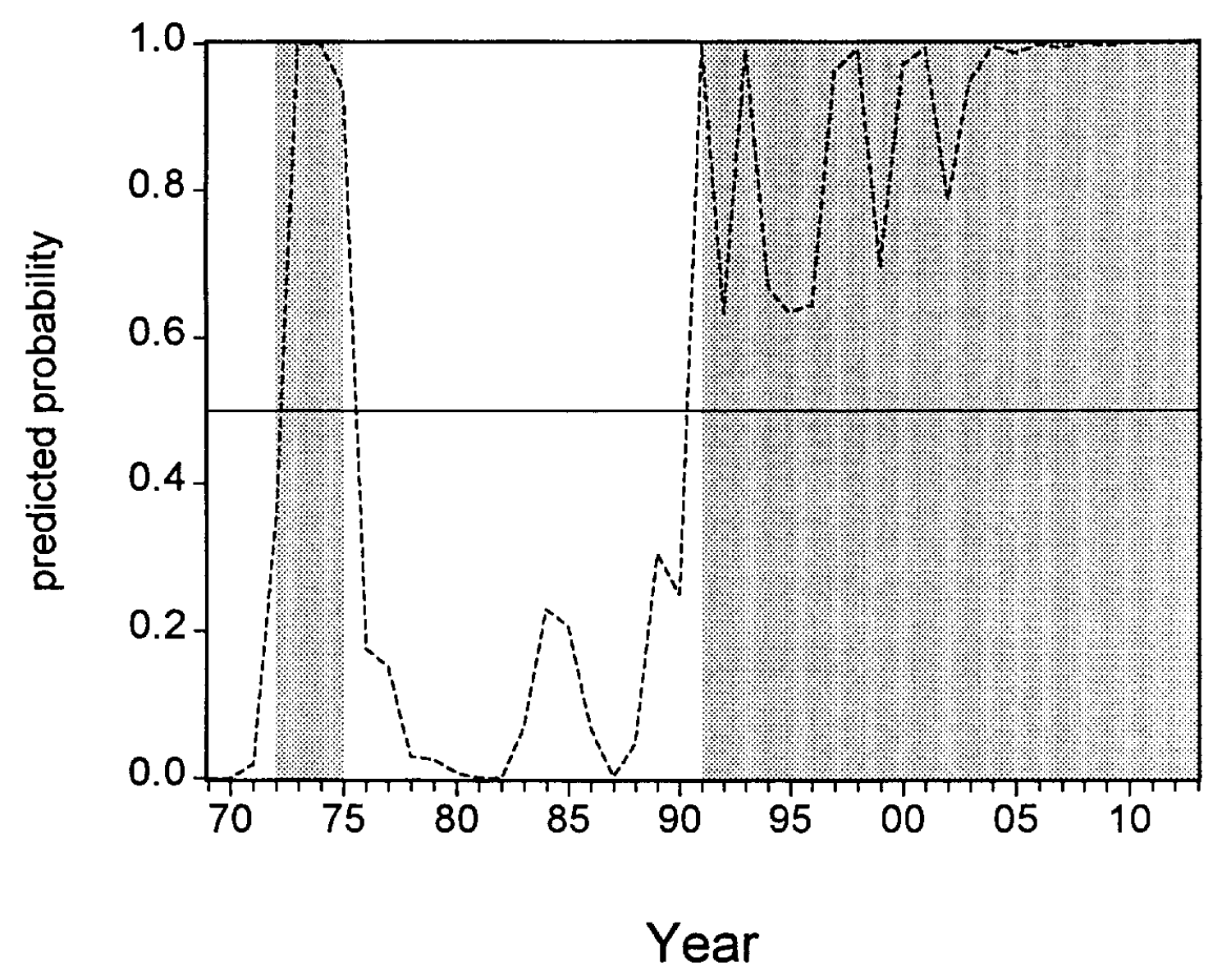


FIGURE 7 (A)

Predicted Probability of Domestic Tinplate Production

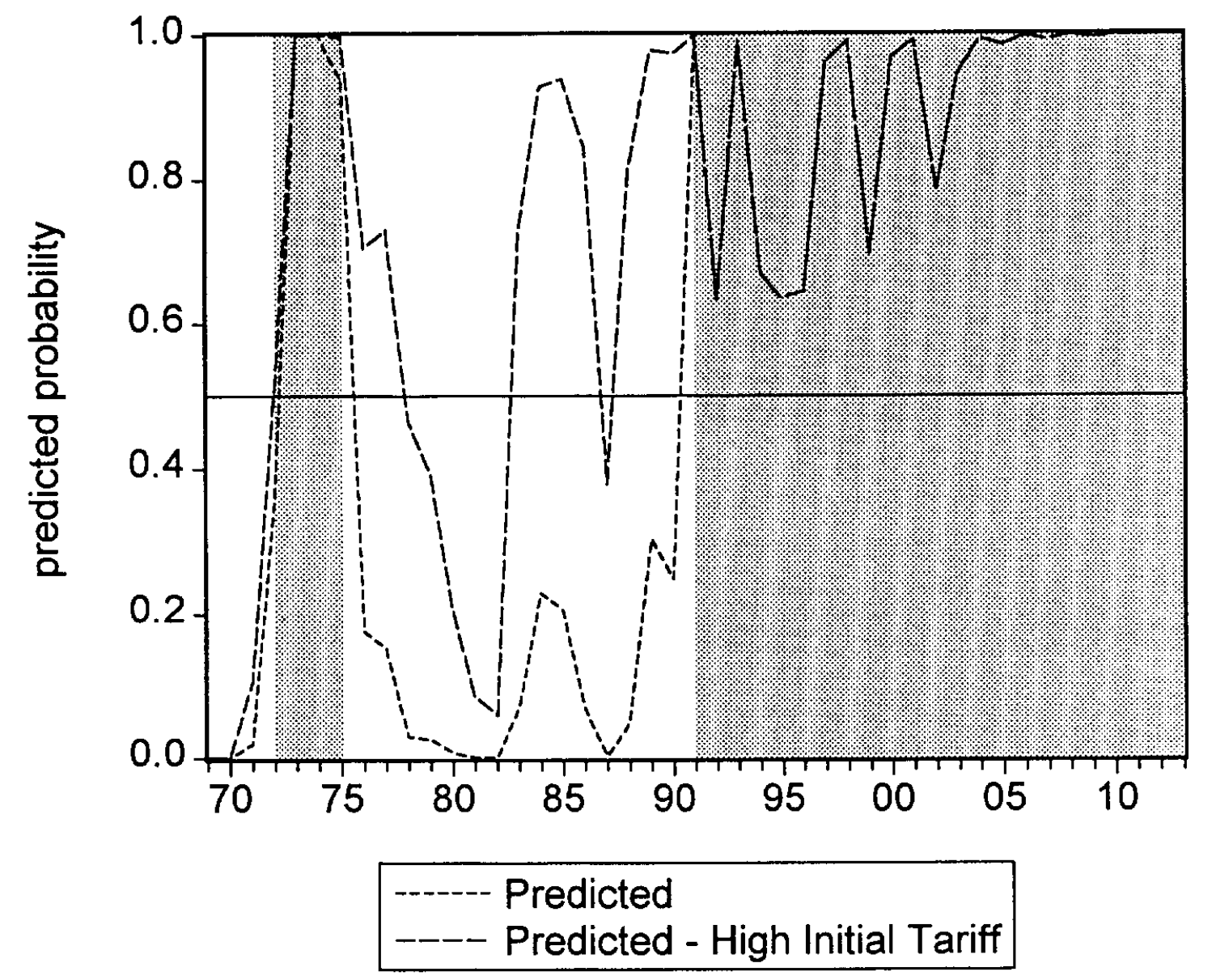




\section{FIGURE 7 (B) \\ Predicted Probability of Domestic Tinplate Production}

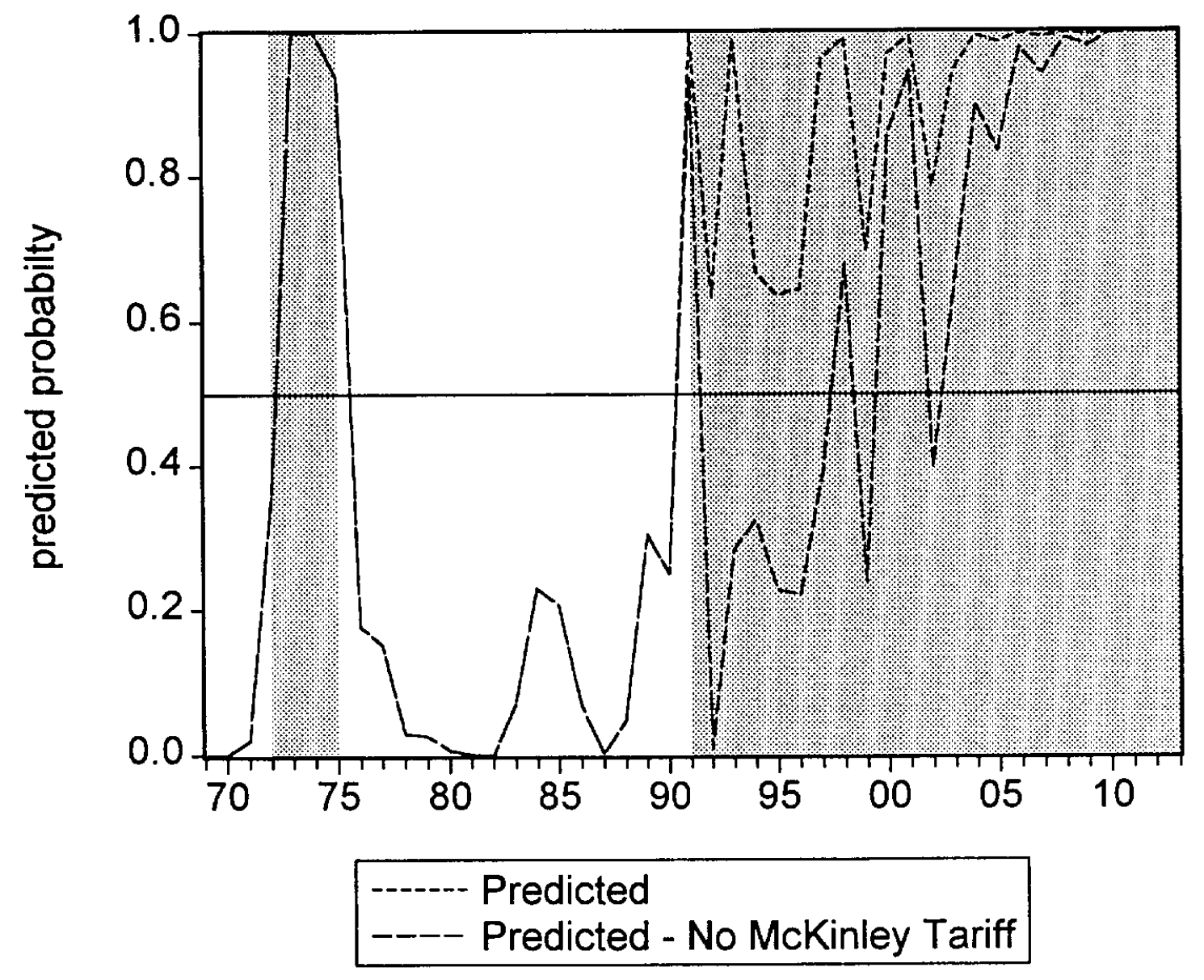




\section{FIGURE 7 (C)}

\section{Predicted Probability of Domestic Tinplate Production}

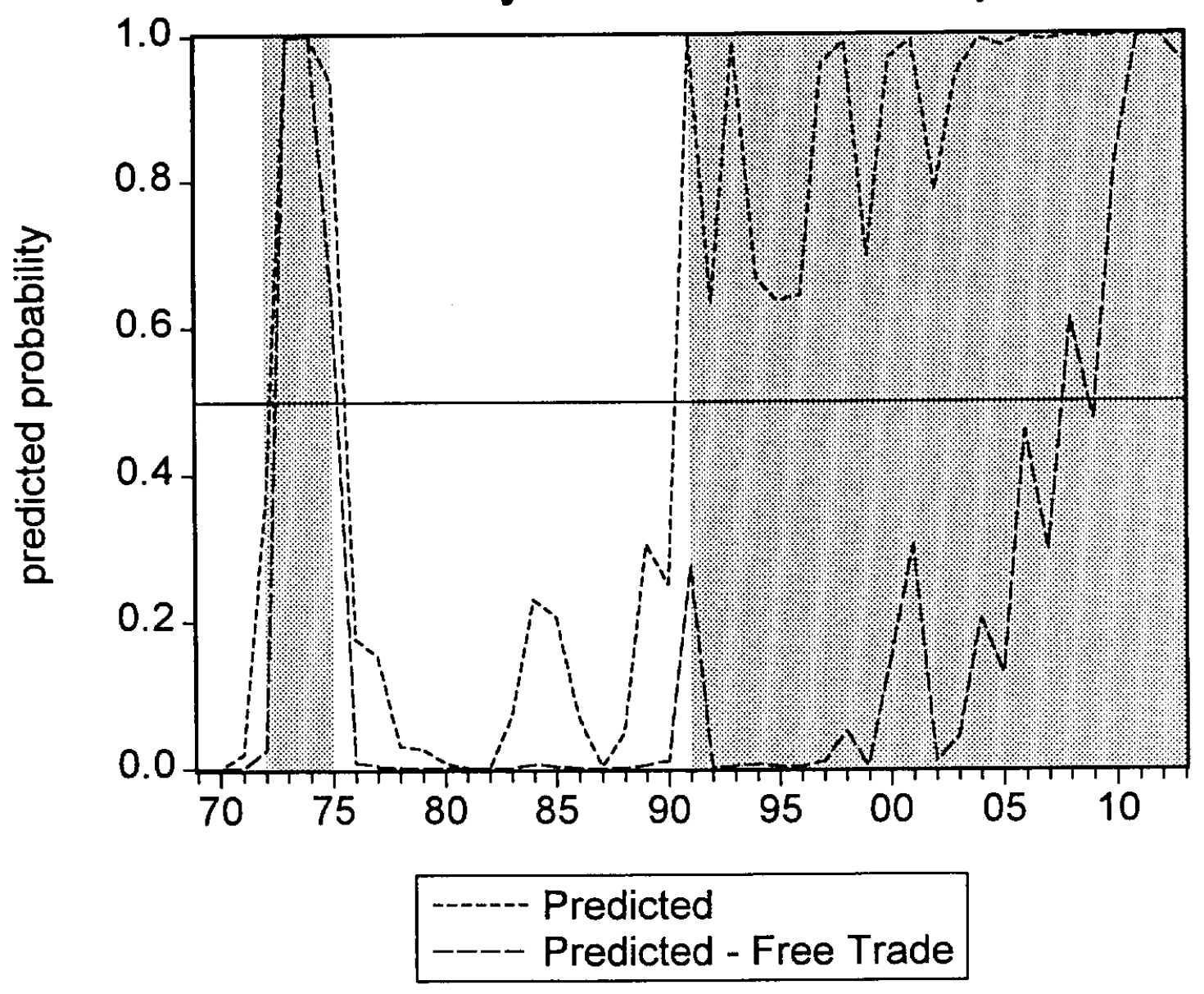


FIGURE 7 (D)

Predicted Probability of Domestic Tinplate Production

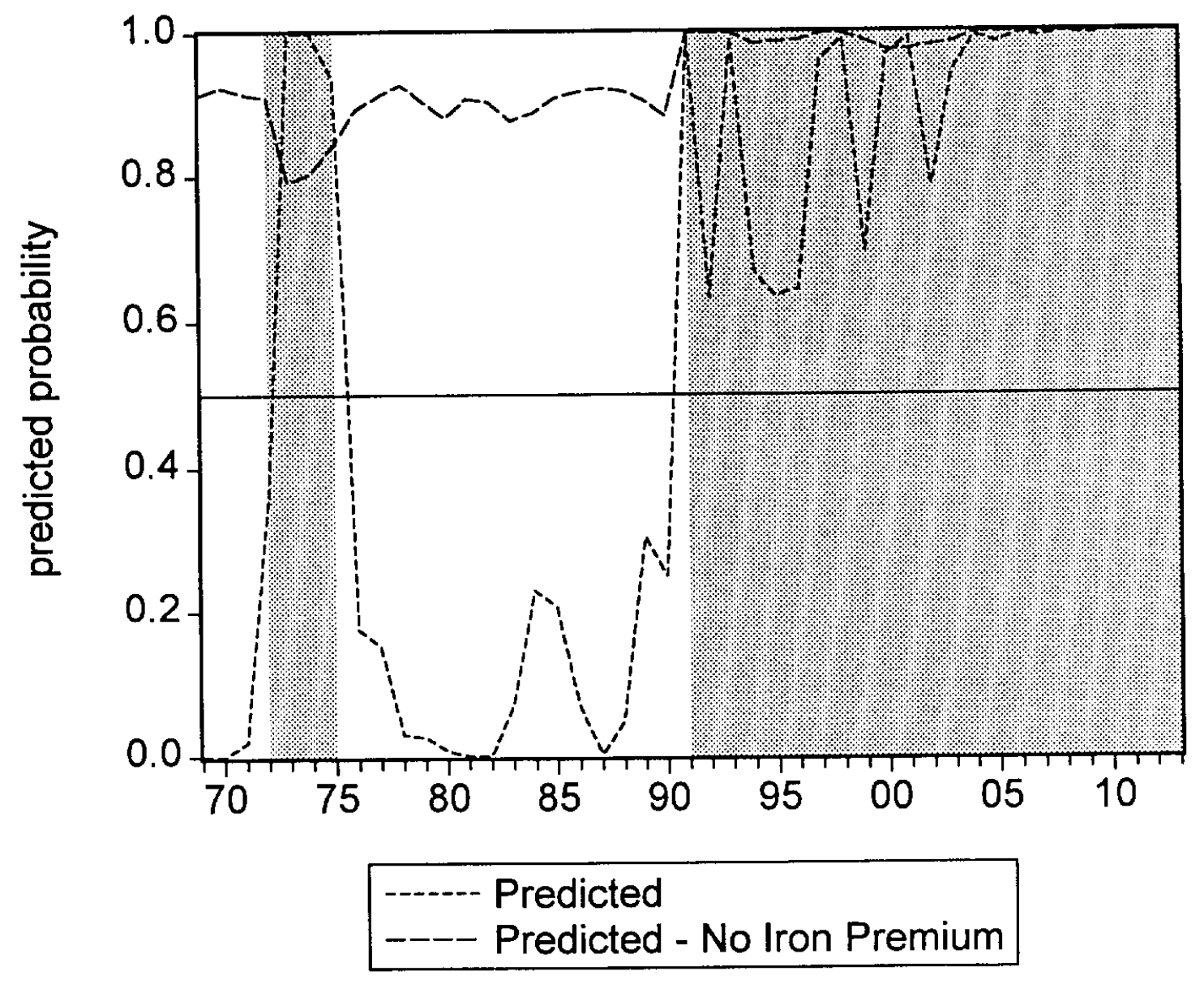

